\title{
Effect of Bisphenol (A) on the Cerebellar Cortex of Albino Rats and Possible Protective Effect of Omega 3
}

\author{
SOHAIR A. SADEK, M.D.; EMAN B. ELSHAL, M.D.; AMANY M. ABO-OUF, M.D. and \\ MONA T. ABD EL-AAL, M.Sc. \\ The Department of Anatomy and Embryology, Faculty of Medicine for Girls, Al-Azhar University, Cairo, Eygpt
}

\begin{abstract}
Background: Bisphenol A is the most commercially used of bisphenol groups in plastic industry. It induces oxidative damage in the brain of rats.

Aim of Study: The present work investigates the adverse effects of bisphenol A $(5 \mathrm{mg} / \mathrm{kg} /$ day $)$ on the cerebellar cortex of albino rat's offspring of treated mothers throughout pregnancy and lactation and the possible protective effect of omega 3.

Material and Methods: Fifty pregnant albino rats were used in this work. They were divided into 4 groups: I- Control group (Group C); half of them did not receive any substance with their pallets (Group CN). The other half were given $0.54 \mathrm{ml}$ of corn oil $/$ rat (Group CR). II- Omega 3 treated group (Group $\mathrm{O}$ ); each rat was given $0.54 \mathrm{ml}$ of corn oil (contained $54 \mathrm{mg}$ of omega 3). III- Bisphenol A treated group (Group B); each rat was given $0.54 \mathrm{ml}$ of corn oil (contained $6.3 \mathrm{mg}$ of bisphenol A). IV- Bisphenol A and omega 3 treated group (Group BO); each rat was given the same dose of bisphenol A in Group B plus the dose of omega 3 in Group O. The treatments were given as a single daily dose orally by gastric tube throughout pregnancy and for 2 weeks after delivery. The cerebelli of the offspring of all groups were extracted at the ends of the 2 nd and 8 th weeks and prepared for light and electron microscopic examination and morphometric study.

Results: Light and electron microscopic examinations and morphometric study showed that bisphenol $\mathrm{A}$ induced various signs of delayed development in the cerebellar cortex. It also induced degeneration and necrosis of the cerebellar cells and nerve fibers in the form of cytoplasmic vacuoles, dilated rough endoplasmic reticulum, swollen and degenerated mitochondria with destructed cristae. Nuclear changes were observed also in form of karyolysis, pyknosis, karyorrhexis and finally nuclear disappearance. Beside that there was decrease in the number of Purkinje cells. The deleterious effects of bisphenol A on the cerebellar cortex were irreversible on stoppage of its administration. However, combined administration of omega 3 with bisphenol A alleviated the majority of its adverse effects.
\end{abstract}

Correspondence to: Dr. Sohair A. Sadek, The Department of Anatomy and Embryology, Faculty of Medicine for Girls, Al-Azhar University, Cairo, Eygpt
Conclusion: It could be concluded that bisphenol A induced various deleterious changes in the histological structure of the cerebellar cortex of albino rat's offspring of treated mothers throughout pregnancy and lactation. These changes were irreversible on withdrawal of bisphenol A. On the other hand combined administration of omega 3 with bisphenol A alleviated most of these changes.

Key Words: Bisphenol A - Pregnant - Albino rats - Cerebellum - Offspring.

\section{Introduction}

BISPHENOLS are group of chemical compounds with two hydroxyphenyl functional groups. The most commercially used is bisphenol A. It is utilized to produce polycarbonates and epoxy resins which are typically clear and hard plastics. These hard plastics are labeled in the market or commercial use with the recycle symbol 7 or may contain the letters PC near the recycle symbol [1,2]. Bisphenol $\mathrm{A}$ is frequently used in the internal coating of food and beverage containers. It provides an effective barrier preventing chemical reactions between the food and the metal wall of the bottle, thereby ensure food safety. Also it is a building block in industrial production of polycarbonate plastics as baby bottles, tableware, food containers, water bottles and dental sealants $[3,4]$. In addition, it is used in the processing of polyvinyl chloride plastic and in the recycling of thermal paper, the type of paper used in some purchase receipts, self-adhesive labels and fax paper. It can also be found as a residue in paper and cardboard food packaging materials [5]. The primary source of exposure to bisphenol A for most people is through the diet [6]. Bisphenol A in food and beverages accounts for the majority of daily human exposure contributes to $10-40 \%$ of the daily intake [7]. Bisphenol A can migrate from the containers into the liquid. The degree of its migration depends more on the temperature of the liquid than 
the date of manufacture. Where, more migration occurs with higher temperatures [8]. Also bisphenol A has wide spread exposure, it causes air pollution and water stream contamination [9]. Bisphenol A generates significantly high concentrations of malondialdehyde in the brain of male rats by induction of oxidative damage [10]. Two families of essential fatty acids; omega- 3 and omega- 6 are required for normal body growth and maturation of many organs, most importantly the brain and eye [11]. Fish and fish oil are rich sources of omega3 fatty acids, specifically eicosapentaenoic acid and docosahexaenoic acid [12]. Alpha-linolenic acid is an omega-3 fatty acid present in seeds, green leafy vegetables, nuts as walnuts and beans as soybeans [13]. Omega-3 fatty acids are found in high concentrations in neuronal membranes and have antioxidant properties [14]

This work aims to investigate the adverse effects of bisphenol A on the cerebellar cortex of albino rat's offspring of treated mothers throughout pregnancy and lactation and the possible protective effect of omega 3.

\section{Material and Methods}

This work was conducted from 9/2016 to 9/2017 at Animal House of Faculty of Medicine for Girls, Al-Azhar University.

\section{Drugs:}

1- Bisphenol $\mathrm{A}$ is available in the form of white solid crystals. It was obtained from LOBA Chemie Company, Cairo, Egypt. According to [15], $5 \mathrm{mg} / \mathrm{kg} /$ day of bisphenol A was used in this work. It is the suggested dose for adult human which resulted in No-Observed-AdverseEffect Level (NOAEL). The equivalent dose for an adult rat was calculated by using the formula of Paget and Barnes [16] to be $6.3 \mathrm{mg} /$ rat. The bisphenol A solution was prepared freshly every day. $256 \mathrm{mg}$ of its solid crystals were dissolved in $22 \mathrm{ml}$ of corn oil. Each pregnant rat was administrated $0.54 \mathrm{ml}$ of corn oil (contained $6.3 \mathrm{mg}$ bisphenol A) orally via a gastric tube once daily.

2- Omega 3 is available in the form of soft gelatin capsules from SEDICO; Pharmaceutical Company, Cairo, Egypt. Each capsule contains $1000 \mathrm{mg}$ of omega 3. According to [17], 3000mg/ day omega 3 was used in this work. It is the average human therapeutic dose. The equivalent dose for an adult rat was calculated by using the formula of Paget and Barnes [16] to be $54 \mathrm{mg} / \mathrm{rat}$. The omega 3 was freshly prepared every day. 6 capsules of omega 3 were dissolved in $54 \mathrm{ml}$ of corn oil. Each capsule nearly contain $1 \mathrm{ml}$ so $6000 \mathrm{mg}$ of omega 3 which dissolved in $54 \mathrm{ml}$ of corn oil considered as present in $60 \mathrm{ml}$ of corn oil. Each pregnant rat was given $0.54 \mathrm{ml}$ of corn oil (contained $54 \mathrm{mg}$ of omega 3 ) orally via a gastric tube once daily.

\section{Animals:}

One hundred and twenty adult albino rats were used in this work ( 80 females and 40 males). Each rat weighted about $200 \mathrm{mg} \pm 20 \mathrm{mg}$. They were bought from the Medical Research Center of the Faculty of Medicine, Ain Shams University. All animals were fed on balanced rat chow and water. The pellets were consisted of 5\% fibers, $3.5 \%$ fats, $6.5 \%$ ash and $20 \%$ proteins. They were housed under a 12/12h light/dark cycle, with free access to feed and water. Room temperature and humidity were maintained at $23 \pm 1^{\circ} \mathrm{C}$ and $55 \pm 5 \%$, respectively. The rats were kept in stainless steel cages. The adult females were isolated from the adult males for two weeks before the beginning of the experiment for acclimatization, and then each male was kept with two females in a separate cage to allow matting. The fifty females that showed vaginal plug considered to be in the first day of pregnancy [18]. The fifty pregnant rats were divided into four groups:

I- Control group (Group C): This group consisted of 20 pregnant rats, they divided equally into:

- Control group N (Group CN): The pregnant rats did not receive any substance with their pallets. Twenty of their offspring were taken at the age of 2 -weeks (CN2). The other twenty offspring were taken at the age of 8-weeks (CN8).

- Control group R (Group CR): Each pregnant rat was administered $0.54 \mathrm{ml}$ of corn oil orally as a single daily dose throughout pregnancy and for 2 weeks after delivery. Twenty of their offspring were taken at the age of 2-weeks (CR2). The other twenty offspring were taken at the age of 8-weeks (CR8).

II- Omega 3 treated group (Group O): This group consisted of 10 pregnant rats. Each pregnant rat was administered $0.54 \mathrm{ml}$ of corn oil (contained $54 \mathrm{mg}$ of omega 3 ) orally as a single daily dose throughout pregnancy and for 2 weeks after delivery. Twenty of their offspring were taken at the age of 2-weeks $\left(\mathrm{O}_{2}\right)$. The other twenty offspring were taken at the age of 8weeks $(\mathrm{O} 8)$.

III- Bisphenol A treated group (Group B): This group consisted of 10 pregnant rats. Each preg- 
nant rat was administered $0.54 \mathrm{ml}$ of corn oil (contained $6.3 \mathrm{mg}$ of bisphenol A orally as a single daily dose throughout pregnancy and for 2 weeks after delivery. Twenty of their offspring were taken at the age of 2-weeks (B2). The other twenty offspring were taken at the age of 8-weeks (B8).

IV- Bisphenol A and omega 3 treated group (Group $B O$ ): This group consisted of 10 pregnant rats. Each pregnant rat was administered the same doses of omega 3 and bisphenol A of the previous groups. Twenty of their offspring were taken at the age of 2-weeks (BO2). The other twenty offspring were taken at the age of 8weeks (BO8).

\section{Collection of the specimens and preparation for examination:}

The offspring of all groups were taken at two time intervals; at 2 and 8 weeks. All of them were carefully examined for any congenital abnormalities. Then they were anaesthetized lightly by diethyl ether inhalation. Special care was done for the rats which used for electron microscopic study to take the specimens while the rat still alive. Each rat of all groups was decapitated with straight, thin and sharp scissors. The cap and side walls of the cranium were carefully removed. The dura mater was carefully incised all around then raised up. The falx cerebri was removed and tentorium cerebelli was cut out. Then the cerebelli were gently removed. Half of them were used for light microscopic examination and morphometric study. The other half was used for Transmission Electron (TEM) microscopic examination.

\section{Light microscopic examination:}

The cerebelli which were used for light microscopic examination were fixed by immersion in Bouin's solution for 3 days. The specimens were dehydrated in ascending grades of ethyl alcohol and cleared in benzene. They were impregnated for three changes in paraffin and were finally embedded in paraffin wax. The paraffin blocks were cut into serial sagittal sections at $5 \mu \mathrm{m}$ thick with a rotary microtome. Successive sagittal paraffin sections were attached to an albumenized glass slides. The Hematoxylin and Eosin stain [19] was used to study the cerebellar architectures. Holmes' method silver staining [20] was used to illustrate the nerve fibers. Also, the cerebellar semithin sections which were stained with toluidine blue were examined by the light microscope. The images were taken by a microscope (Leica) DM750 connected to a digital camera in Anatomy Depart- ment, Faculty of Medicine for Girls, Al-Azhar University, Cairo, Egypt.

\section{Transmission electron microscopic examination:}

The cerebelli which used for electron microscopic examination were cut into small pieces. The specimens were immediately fixed in cold 5\% glutaraldehyde and washed in $0.1 \mathrm{ml}$ phosphate buffer (PH 7.2). Then, post fixed with $1 \%$ osmium tetraoxide $\left(\mathrm{OsO}_{4}\right)$, dehydrated and embedded in epoxy resin. The semi thin sections ( $1 \mu \mathrm{m}$ thick) were cut on an LKB ultratome and stained with toluidine blue and examined by light microscope. Ultrathin sections (60nm thick) were cut, mounted on copper grids, and stained with uranyl acetate and lead citrate [19]. The ultrathin Sections were examined using a transmission electron microscope (JEOL1010 EX II, Japan) at the Regional Mycology and Biotechnology Center, Al-Azhar University, Cairo, Egypt.

\section{Morphometric study:}

The image analyzer computer system Leica Qwin 500 (England) at the Regional Mycology and Biotechnology Center, Al-Azhar University, Cairo, Egypt was used to evaluate the thickness of the molecular layer and the number of the Purkinje cells of the studied groups using H. \& E.-stained sections. The ten slides of ten offspring albino rats were taken at the mid sagittal sections of all groups. Then the five central folia were selected in each slide to measure the thickness of the molecular layer and to count the number of Purkinje cells. Measuring the thickness was done by taking 6 different thicknesses for each folium at magnification X 100 using Image J software version 1.48. Counting the number of Purkinje cells of the folia was done in fixed parts of the studied folia in special fixed squares. The means of the thickness of the molecular layer and the means of the numbers of the Purkinje cells of each folium were calculated. The cumulative mean thickness and mean number of Purkinje cells for each group were calculated statistically. The data was subjected to statistical analysis.

\section{Statistical analysis:}

Statistical analysis of the data obtained were expressed as mean values and standard deviations, and statistical significance was determined by oneway analysis of variance (ANOVA) followed by Tukey's post hoc test for multiple comparison [21] Differences were considered statistically highly significant at $(p<0.01)$. 


\section{Results}

Macroscopic result: Macroscopic examination of the offspring at birth revealed no congenital anomalies and no mortality rats.

\section{Microscopic result:}

Cerebellar cortex of 2 weeks old albino rat offspring of mothers group:

- Cerebellar cortex of 2-weeks old offspring of the control ( $\mathrm{CN} 2$ and $\mathrm{CR} 2)$ and omega $3\left(\mathrm{O}_{2}\right)$ treated mothers groups:

Light and electron microscopic examinations of the cerebellar cortex of 2-weeks old albino rat offspring of the control (CN2 and CR2) and omega $3\left(\mathrm{O}_{2}\right)$ treated mothers groups showed insignificant histological differences so their data were pooled together.

Light microscopic examination of the haematoxylin and eosin and toluidine blue stained midsagittal sections of the cerebellar cortex of 2-weeks old offspring of the control (CN2 and CR2) and omega 3 treated $\left(\mathrm{O}_{2}\right)$ mothers group showed that the cerebellar cortex consisted of four layers; the external granular layer, the molecular layer, the Purkinje cell layer and the internal granular layer. The external granular layer lied beneath the pia mater and consisted of 2-3 rows of external granular cells. The external granular cells were variable in size, rounded or oval in shape and had deeply stained nuclei with prominent nucleoli Fig. (1A). The molecular layer consisted of 2 types of cells; stellate and basket cells. The migrating granular cells could also be seen. The stellate cells were present in the outer part of the molecular layer. The basket cells were present in the deep part of the molecular layer and in between the Purkinje cells. Both of them were also present in the middle part. They were variable in size, oval or rounded in shape and had lightly stained nuclei with prominent nucleoli. The Purkinje cells arranged in a single row. Most of them appeared oval in shape and some of them accepted their characteristic flask shape. They had large rounded vesicular nuclei with prominent nucleoli. The internal granular layer was formed of internal granular cells which were arranged in clusters that were separated by small acidophilic areas that represent the cerebellar glomeruli. The internal granular cells were variable in size, rounded or oval in shape and had deeply stained nuclei with prominent nucleoli Figs. $(1 \mathrm{~A}, \mathrm{~B})$.

Electron microscopic examination of the cerebellar cortex of 2-weeks old offspring of the control
(CN2 and CR2) and omega 3 treated $\left(\mathrm{O}_{2}\right)$ mothers groups showed that the external granular cells lied beneath the pia mater. They had large heterochromatic nuclei with prominent nucleoli. Their cytoplasm contained free ribosomes, few rough endoplasmic reticulum, and rounded or oval mitochondria Fig. (1C). The molecular layer composed of a complex network of neuronal cells; stellate and basket cells and nerve fibers; axons and dendrites. The stellate and basket cells had indented euchromatic nuclei with small clumps of heterochromatin with eccentric nucleoli and apparent nuclear pores. Their cytoplasm contained free and clusters of ribosomes, rough endoplasmic reticulum and rounded or elongated mitochondria. The dendrites contained mitochondria and parallel microtubules and neurofilaments. The axons contained vesicles of varying size Fig. (1D). The Purkinje cells had rounded euchromatic nuclei with eccentric nucleoli and deep invaginations. Their cytoplasm contained free and clusters of ribosomes, rough endoplasmic reticulum, rounded or elongated mitochondria and lysosomes Fig. (1E). The internal granular cells lied close together and had heterochromatic nuclei with eccentric nucleoli. Their cytoplasm contained, free ribosomes, rough endoplasmic reticulum, and small rounded or oval mitochondria Fig. (1F).

Morphometric study of the cerebellar cortex of 2 -weeks old offspring of the control (CN2 and $\mathrm{CR} 2)$ and omega 3 treated $\left(\mathrm{O}_{2}\right)$ mothers groups showed insignificant difference $(p>0.05)$ in the means of the thickness of the molecular layers and the means of the number of the Purkinje cells between $\mathrm{CN} 2, \mathrm{CR} 2$ and $\mathrm{O}_{2}$ offspring (Table 1) and Graph (1).

\section{- Cerebellar cortex of 2-weeks old offspring of bisphenol A (B2) treated mothers group:}

Light microscopic examination of the haematoxylin and eosin and toluidine blue stained midsagittal sections of the cerebellar cortex of 2-weeks old albino rat offspring of bisphenol A (B2) treated mothers group showed that the cerebellar cortex consisted of four layers; the external granular layer, the molecular layer, the Purkinje cell layer and the internal granular layer Fig. (2A). The external granular layer lied beneath the pia mater and consisted of 7-13 rows of external granular cells. The majority of the external granular cells had irregular appearance, vacuolated cytoplasm and few of them had nuclear changes in the form of shrunken deeply stained nuclei and nuclear fragmentation. The majority of the stellate cells appeared irregular in shape. The irregular migrating granular cells could 
also be detected in the molecular layer. Few basket cells appeared irregular in shape and other cells had vacuolated cytoplasm. Some Purkinje cells appeared irregular in shape and had ill-defined outlines and nuclei. The majority of internal granular cells appeared more or less similar to the control one. They arranged in clusters separated by the cerebellar glomeruli but few of them appeared with irregularity in shape and others had vacuolated cytoplasm Figs. (2A,B) and Figs. $(1 \mathrm{~A}, \mathrm{~B})$.

Electron microscopic examination of the cerebellar cortex of 2-weeks old albino rat offspring of bisphenol A (B2) treated mothers group showed that the external granular cells had fragmented nuclei and mitochondria with destructed cristae Fig. (2C). Few stellate cells had partially ill-defined outlines, their nuclei were heterochromatic and their cytoplasm contained swollen mitochondria with destructed cristae and few dilated rough endoplasmic reticulum. The majority of basket cells had ill-defined outlines. Their nuclei were euchromatic with disappearance of heterochromatin contents as compared with the control one. Other cells had shrunken nuclei with condensed clumps of heterochromatin. Their cytoplasm contained mitochondria with destructed cristae, numerous dilated rough endoplasmic reticulum and numerous vacuoles. Some dendrites with numerous dilated rough endoplasmic reticulum could be detected. Figs. (2D,E) and Fig. (1D). The majority of Purkinje cells had ill-defined nuclei. Their cytoplasm contained numerous swollen mitochondria with destructed cristae. The rough endoplasmic reticulum appeared more or less similar to the control one Figs. (2E,1E). Few internal granular cells had illdefined outlines and shrunken nuclei with condensed clumps of heterochromatin. The cytoplasm of other cells contained swollen mitochondria with destructed cristae Fig. (2F).

Morphometric study of the cerebellar cortex of 2-weeks old offspring of bisphenol A (B2) treated mothers group showed highly significant decrease $(p<0.01)$ in the means of the thickness of the molecular layers and the means of the number of the Purkinje cells of B2 than CN2, CR2, $\mathrm{O}_{2}$ and BO2 offspring (Table 1) and Graph (1).

\section{- Cerebellar cortex of 2 weeks old offspring of combined bisphenol A and omega 3 (BO2) treated mothers group:}

Light microscopic examination of the haematoxylin and eosin and toluidine blue stained midsagittal sections of the cerebellar cortex of 2-weeks old albino rat offspring of combined bisphenol A and omega 3 (BO2) treated mothers group showed that the cerebellar cortex was consisted of four layers; the external granular layer which lied beneath the pia mater, the molecular layer, the Purkinje cell layer and the internal granular layer. The rows of the external granular cells were 2-5. The external granular, the molecular, the Purkinje and the internal granular cells appeared more or less similar to those of the control and omega 3 treated mothers groups Figs. (3A,B) and Figs. (1A,B).

Electron microscopic examination of the cerebellar cortex of 2-weeks old albino rat offspring of combined bisphenol A and omega 3 (BO2) treated mothers group showed that the cerebellar cells and nerve fibers appeared more or less similar to the control and omega 3 treated mothers groups. However, few basket cells still had small cytoplasmic vacuoles and few dilated rough endoplasmic reticulum. Also few internal granular cells still had few mitochondria with destructed cristae Figs. (3C-F) and Figs. (1C-F).

Morphometric study of the cerebellar cortex of 2-weeks old albino rat offspring of combined bisphenol A and omega 3 (BO2) treated mothers group showed insignificant $(p>0.05)$ difference in the means of the thickness of the molecular layer and the means of the numbers of the Purkinje cells between $\mathrm{BO} 2, \mathrm{CN} 2, \mathrm{CR} 2$, and $\mathrm{O}_{2}$ (Table 1) and Graph (1).

Cerebellar cortex of 8-weeks old albino rat offspring of mothers groups:

- Cerebellar cortex of 8-weeks old offspring of the control (CN8 and CR8) and omega 3 (O8) treated mothers groups:

Light and electron microscopic examinations of the cerebellar cortex of 8-weeks old albino rat offspring of the control (CN8 and CR8) and omega $3(\mathrm{O} 8)$ treated mothers groups showed insignificant histological differences so their data were pooled together.

Light microscopic examination of the haematoxylin and eosin and toluidine blue stained midsagittal sections of the cerebellar cortex of 8-weeks old albino rat offspring of the control (CN8, CR8) and omega $3(\mathrm{O} 8)$ treated mothers groups showed that the cerebellar cortex consisted of three layers; the molecular layer, the Purkinj e cell layer and the internal granular layer. The molecular layer lied beneath the pia mater. Its thickness was markedly increased than the previous age. It consisted of 2 types of cells; stellate and basket cells. The stellate 
cells present in the outer part of the molecular layer, they appeared oval or fusiform in shape. The basket cells present in the deep part of the molecular layer and in between the Purkinje cells, they appeared oval or rounded in shape. The stellate and basket cells had lightly stained nuclei with prominent nucleoli. The middle part of the molecular layer contained both types of cells Figs. (4A,B). The Purkinje cells were arranged in a single row. They achieved the typical flask shape and had large central vesicular nuclei with prominent nucleoli Fig. (4A). The internal granular layer consisted of internal granular cells which arranged in clusters that were separated by small acidophilic areas called the cerebellar glomeruli. The internal granular cells appeared nearly rounded in shape and more or less equal in size. They had deeply stained nuclei with prominent nucleoli Fig. (4A). The sections of the cerebellar cortex which stained with Holmes' method silver staining showed that the nerve fibers of the molecular layer appeared as thin, elongated brown filaments that were distributed in different directions. The dendrites of the Purkinje cells were directed towards the molecular layer. The axons were directed towards the internal granular layer. The nerve fibers of the internal granular layer appeared long and extended in different directions Fig. (4C).

Electron microscopic examination of the cerebellar cortex of 8-weeks old offspring of the control (CN8, CR8) and omega 3 (O8) treated mothers groups showed that the stellate cells had characteristically euchromatic nuclei with small clumps of heterochromatin. The nuclei had deep invaginations, apparent nuclear pores, and eccentric nucleoli. Their cytoplasm contained free and clusters of ribosomes, rough endoplasmic reticulum, rounded and elongated mitochondria and Golgi apparatus. The basket cells had large indented euchromatic nuclei with small clumps of heterochromatin. Their cytoplasm contained free ribosomes and few rounded or elongated mitochondria Fig. (4D). The neuropil of the molecular layer consisted of dendrites and axons. The dendrites contained mitochondria, rough endoplasmic reticulum, parallel microtubules and neurofilaments. The axons were varying in size and contained vesicles of varying size Fig. (4D). The Purkinje cells had euchromatic nuclei with shallow and deep invaginations with apparent nuclear pores. Their cytoplasm contained free and clusters of ribosomes, rough endoplasmic reticulum, rounded or elongated mitochondria and lysosomes Fig. (4E). The internal granular cells were close with each other and had heterochromatic nuclei with eccentric nucleoli. Their cytoplasm contained free ribosomes, few rough endoplasmic reticulum and small rounded or oval mitochondria Fig. (4F).

Morphometric study of the cerebellar cortex of 8-weeks old offspring of the control (CN8, CR8) and omega $3(\mathrm{O} 8)$ treated mothers groups showed insignificant difference $(p>0.05)$ in the means of the thickness of the molecular layers and the means of the numbers of the Purkinje cells between CN8, CR8 and O8 offspring (Table 2) and Graph (2).

\section{- Cerebellar cortex of 8-weeks old offspring of bisphenol A (B8) treated mothers group:}

Light microscopic examination of the haematoxylin and eosin and toluidine blue stained midsagittal sections of the cerebellar cortex of 8-weeks offspring of bisphinol A (B8) treated mothers group showed that the cerebellar cortex consisted of 3 layers; the molecular layer, the Purkinje cell layer and the internal granular layer. The molecular layer lied just beneath the pia mater. Some stellate cells were irregular in shape and had shrunken deeply stained nuclei. Other cells had vacuolated cytoplasm. The majority of basket cells had vacuolated cytoplasm. The majority of Purkinje cells appeared irregular in shape and had ill-defined nuclei and surrounded by areas of vacuolations. The nuclei of few Purkinje cells disappeared leaving cellular debris. The internal granular cells appeared more or less similar to the control one. However, few cells had shrunken deeply stained nuclei Figs. (5A,B) and Figs. (4A,B). The sections of the cerebellar cortex which were stained with Holmes' method silver staining showed that the nerve fibers of the molecular layer appeared few, short and fragmented. The dendrites and axons of the Purkinje cells appear thin and short. The nerve fibers of the internal granular layer appeared few and fragmented as compared with the control one Figs. (4C,5C).

Electron microscopic examination of the cerebellar cortex of 8-weeks old albino rat offspring of bisphenol A (B8) treated mothers group showed that few stellate cells had ill-defined outlines and heterochromatic nuclei with eccentric nucleoli and deep invagination. Their cytoplasm contained swollen mitochondria with destructed cristae and numerous vacuoles. The majority of basket cells had euchromatic nuclei with absence of their heterochromatin clumps. Their cytoplasm contained numerous vacuoles and mitochondria with destructed cristae. The neuropil of the molecular layer contained many swollen dendrites with dilated rough endoplasmic reticulum, swollen and degenerated mitochondria and areas of ill-defined struc- 
tures as compared with the control one Figs. (5D,E) and Fig. (4D). The majority of Purkinje cells had ill-defined nuclei, swollen mitochondria with destructed cristae and dilated rough endoplasmic reticulum as compared with the control one Figs. (4E,5E). The majority of internal granular cells had heterochromatic nuclei with eccentric nuclei and their cytoplasm contained swollen mitochondria with destructed cristae. However, few of them had ill-defined outlines and irregular and shrunken nuclei with condensed clumps of heterochromatin as compared with the control one Figs. (4F,5F).

Morphometric study of the cerebellar cortex of 8 -weeks old offspring of bisphenol A (B8) treated mothers group showed highly significant $(p<0.01)$ decrease in the means of the thickness of the molecular layers and the means of the numbers of the Purkinje cells than CN8, CR8, O8 and BO8 offspring (Table 2) and Graph (2).

\section{- Cerebellar cortex of 8-weeks old offspring of combined bisphenol A and omega 3 (BO8) treated mothers group:}

Light microscopic examination of the haematoxylin and eosin and toluidine blue stained midsagittal sections of the cerebellar cortex of 8-weeks old albino rat offspring of bisphenol A and omega 3 (BO8) treated mothers group showed that the cerebellar cortex consisted of three layers; the molecular layer, the Purkinje cell layer and the internal granular layer. It also showed that the molecular, the Purkinje and the internal granular cells appeared more or less similar to those of the

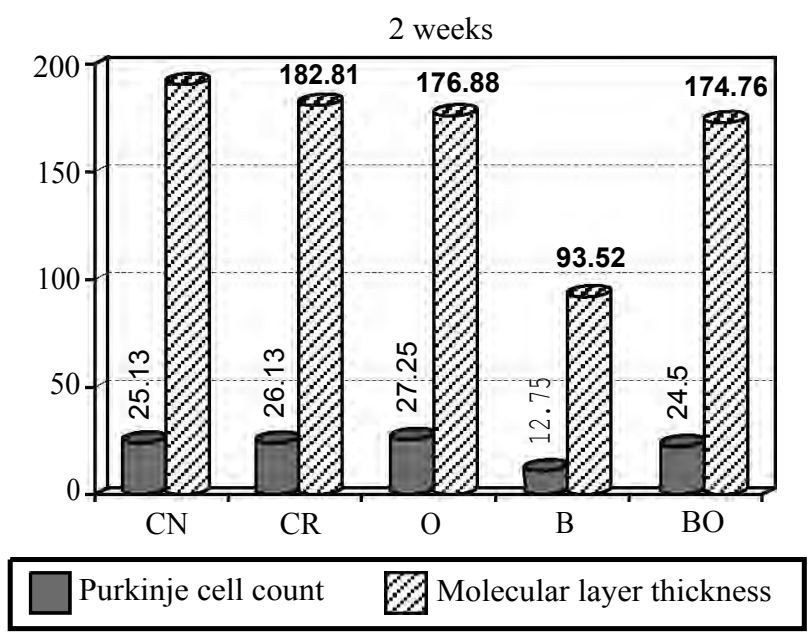

Graph (1): Bar chart representing the means of the number of the Purkinje cells and the thickness of the molecular layer of the cerebellar cortex of the 2weeks old offspring of the studied groups. control and omega 3 treated groups Figs. $(6 \mathrm{~A}, \mathrm{~B})$ and Fig. (4A). The sections of the cerebellar cortex which were stained with Holmes' method silver staining showed that the fibers of the molecular layer appeared elongated and distributed in different directions. The dendrites of the Purkinje cells were directed towards the molecular layer. The axons were directed towards the internal granular layer. The nerve fibers of the internal granular layer appeared long and extended in different directions as compared with the control and omega 3 treated mothrs groups Figs. (4A,6C).

Electron microscopic examination of the cerebellar cortex of 8-weeks old albino rat offspring of bisphenol A and omega 3 (BO8) treated mothers group showed that the cerebellar cells and nerve fibres appeared more or less similar to the control and omega 3 treated mothers groups. However, few stellate cells had scanty mitochondria with destructed cristae, few basket cells still had small cytoplasmic vacuoles. In addition, few Purkinje cells had scanty dilated rough endoplasmic reticulum. Moreover, few internal granular cells still had few mitochondria with destructed cristae Figs. (6D-F) and Figs. (4D-F).

Morphometric study of the cerebellar cortex of 8-weeks old offspring of combined bisphebol A and omega 3 (BO8) treated mothers groups showed insignificant $(p>0.05)$ difference in the means of the thickness of the molecular layer and the means of the numbers of the Purkinje cells between BO8, CN8, CR8, and O8 (Table 2) and Graph (2).

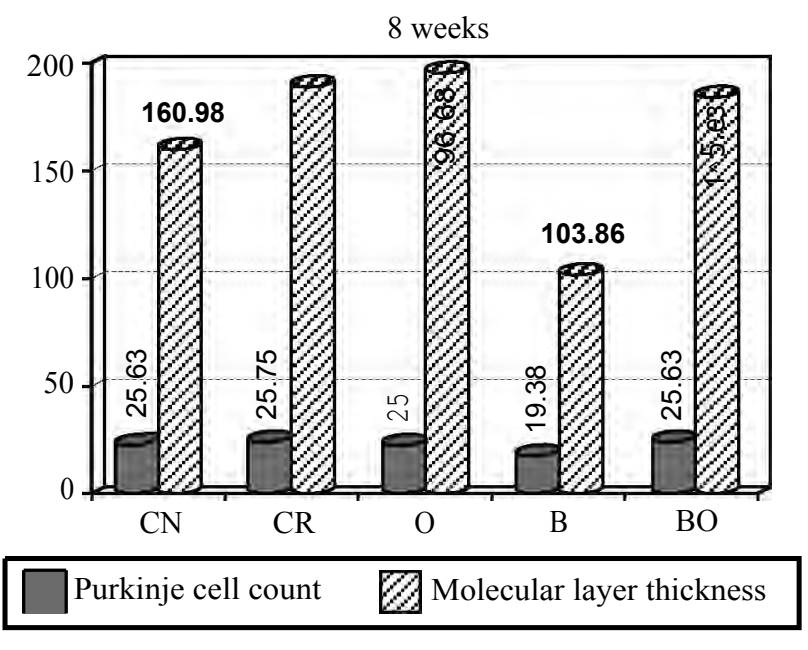

Graph (2): Bar chart representing the means of the number of the Purkinje cells and the thickness of the molecular layer of the cerebellar cortex of the 8weeks old offspring of the studied groups. 

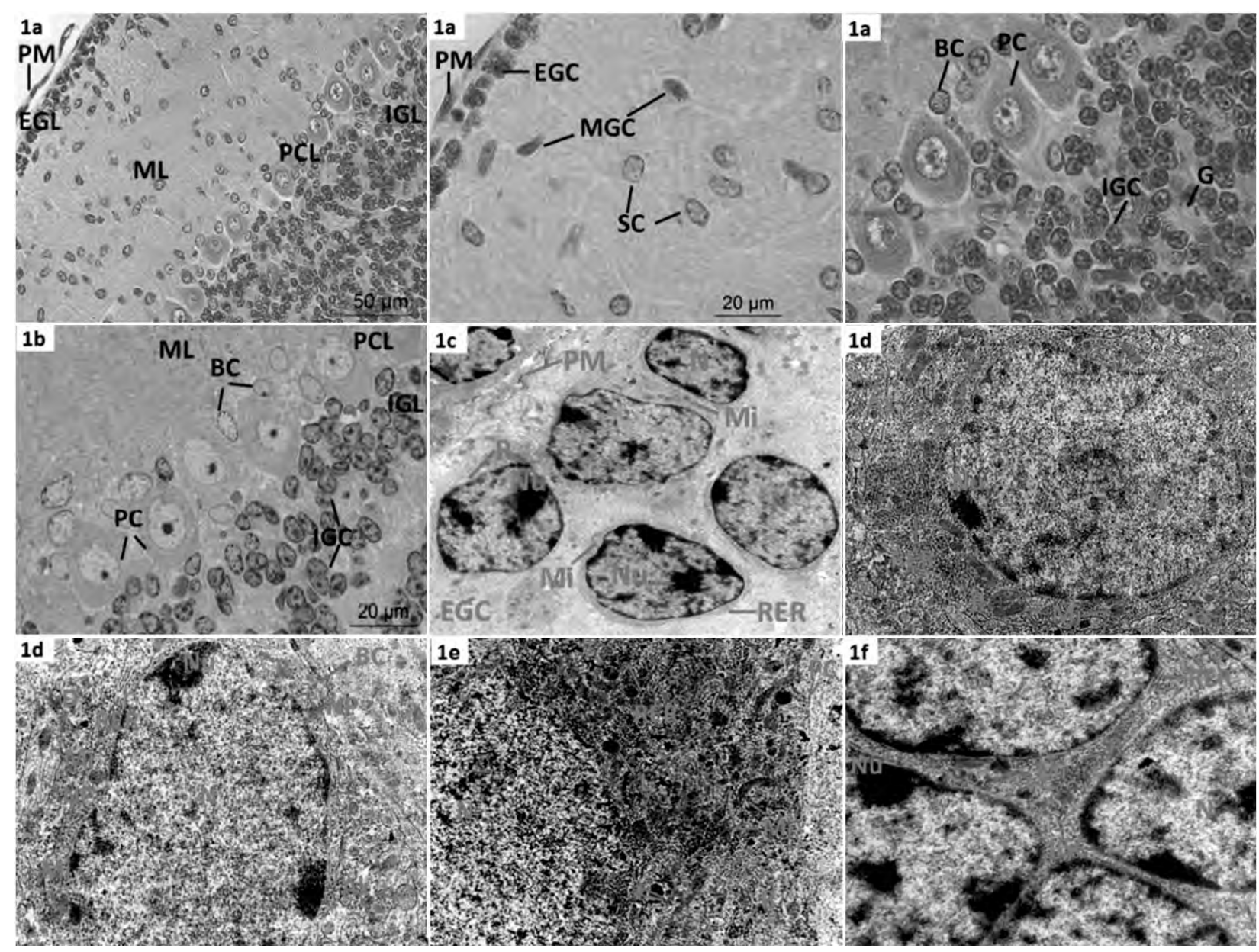

Fig. (1A): Photomicrographs of a median sagittal section of the cerebellar cortex of 2-weeks old offspring of the control $(\mathrm{CN} 2$ and $\mathrm{CR} 2)$ and omega $3\left(\mathrm{O}_{2}\right)$ treated mothers groups show that the cerebellar cortex consists of external granular layer (EGL) lies beneath the pia mater (PM), molecular layer (ML), Purkinje cell layer (PCL) and internal granular layer (IGL). The external granular cells (EGC) arrange in 2-3 rows and have deeply stained nuclei with prominent nucleoli. The stellate (SC) and the basket (BC) cells have lightly stained nuclei with prominent nucleoli. Migrating granular cells (MGC) can be seen. The Purkinje cells (PC) have large rounded vesicular nuclei with prominent nucleoli. The internal granular cells (IGC) arrange in clusters that are separated by the cerebellar glomeruli $(\mathrm{G})$. They have deeply stained nuclei with prominent nucleoli. (H. \& E. $\mathrm{X} 400$ \& X1000).

Fig. (1B): A photomicrograph of a median sagittal section of the lower part of the cerebellar cortex of 2-weeks old offspring of the control (CN2 and CR2) and omega $3\left(\mathrm{O}_{2}\right)$ treated mothers groups shows parts of the molecular layer (ML), Purkinje cell layer (PCL) and the internal granular layer (IGL). The basket cells (BC) have lightly stained nuclei with prominent nucleoli. The Purkinje cells (PC) have large rounded vesicular nuclei with prominent nucleoli. The internal granular cells (IGC) arrange in clusters and have deeply stained nuclei with prominent nucleoli. (Toluidine blue X1000).

Fig. (1C): Electron micrograph of the external granular cells of 2-weeks old offspring of the control (CN2 and CR2) and omega $3\left(\mathrm{O}_{2}\right)$ treated mothers groups shows that the external granular cells (EGC) lie beneath the pia mater (PM). They have heterochromatic nuclei $(\mathrm{N})$ with prominent nucleoli $(\mathrm{Nu})$. Their cytoplasm contains free ribosomes $(\mathrm{R})$, few rough endoplasmic reticulum (RER), and rounded or oval mitochondria (Mi). (TEM X15000).

Fig. (1D): Electron micrographs of the molecular layer of 2-weeks old offspring of the control (CN2 and CR2) and omega $3\left(\mathrm{O}_{2}\right)$ treated mothers groups show that the stellate (SC) and basket (BC) cells have indented euchromatic nuclei with small clumps of heterochromatin $(\mathrm{N})$, eccentric nucleoli $(\mathrm{Nu})$, and apparent nuclear pores (NP). Their cytoplasm contains free ribosomes (R), mitochondria (Mi) and rough endoplasmic reticulum (RER). Notice the presence of axons (Ax) and dendrites (D) with mitochondria (Mi) and microtubules and neurofilaments (NF). (TEM X15000).

Fig. (1E): Electron micrograph of a Purkinje cell of 2-weeks old offspring of the control (CN2 and CR2) and omega 3 (O 2$)$ treated mothers groups shows that the Purkinje cell (PC) has euchromatic nucleus (N) with deep invagination ( 2 arrows). Its cytoplasm contains free and clusters of ribosomes (R), rough endoplasmic reticulums (RER), rounded or elongated mitochondria (Mi) and lysosomes (L). (TEM X15000).

Fig. (1F): Electron micrograph of the internal granular cells of 2-weeks old offspring of the control (CN2 and CR2) and omega $3\left(\mathrm{O}_{2}\right)$ treated mothers groups shows that the internal granular cells (IGC) have heterochromatic nuclei (N) with eccentric nucleoli $(\mathrm{Nu})$. Their cytoplasm contains, free ribosomes $(\mathrm{R})$, rough endoplasmic reticulum (RER), and small rounded or oval mitochondria (Mi). (TEM X15000). 

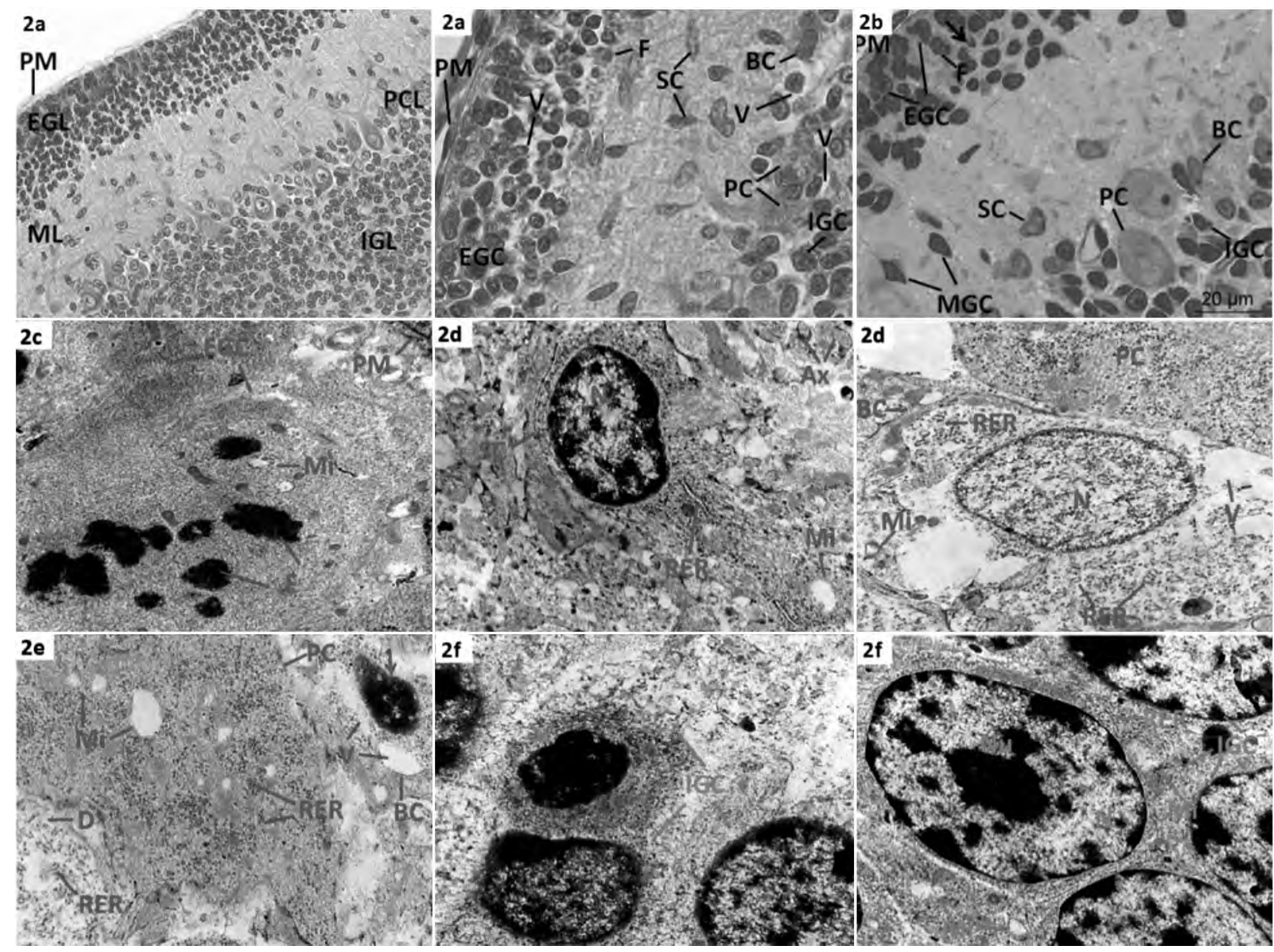

Fig. (2A): Photomicrographs of a median sagittal sections of the cerebellar cortex of 2-weeks old albino rat offspring of bisphenol A (B2) treated mothers group show that the cerebellar cortex consists of external granular layer (EGL) lies beneath the pia mater (PM), molecular layer (ML), Purkinje cell layer (PCL) and internal granular layer (IGL). The external granular cells (EGC) arrange in 7-13 rows, the majority of them have vacuolated (V) cytoplasm. Notice the presence of fragmented nuclei (F). The Stellate cells appear irregular in shape (SC). Few basket cells appear irregular in shape (BC) and others have vacuolated cytoplasm (V). The Purkinje cells appear irregular in shape and have ill-defined outlines and nuclei (PC). Few internal granular cells appear irregular in shape (IGC) and others have vacuolated cytoplasm (V). (H. \& E. X400 \& X1000).

Fig. (2B): A photomicrograph of a median sagittal section of the cerebellar cortex of 2-weeks old albino rat offspring of bisphenol A (B2) treated mothers group shows that the external granular cells (EGC) lay beneath the pia mater (PM). The majority of them have irregular appearance and few of them have shrunken deeply stained nuclei $(\rightarrow)$ and others have fragmented nuclei (F). The stellate (SC) and basket (BC) cells appear with irregularity in shape. Notice the presence of the irregular migrating granular cells (MGC). The Purkinje cells have ill-defined nuclei (PC). The internal granular cells also appear with irregularity in shape (IGC). (Toluidine blue X1000).

Fig. (2C): Eelectron micrograph of the external granular cells of 2-weeks old albino rat offspring of bisphenol A (B2) treated mothers group shows that the external granular cells (EGC) lie beneath the pia mater (PM) and have fragmented nuclei $(\mathrm{F})$ and mitochondria with destructed cristae (Mi). (TEM X15000).

Fig. (2D): Electron micrographs of the molecular layer of 2-weeks old albino rat offspring of bisphenol A (B2) treated mothers group show that a stellate cell (SC) has partially ill-defined outlines, heterochromatic nucleus (N), swollen mitochondria with destructed cristae (Mi) and few dilated rough endoplasmic reticulum (RER). The basket cell (BC) has euchromatic nucleus $(\mathrm{N})$, mitochondria with destructed cristae (Mi), dilated rough endoplasmic reticulum (RER) and cytoplasmic vacuoles (V). Notice the presence of axons (AX) and a part of Purkinje cell (PC). (TEM X15000).

Fig. (2E): Electron micrograph of the cerebellar cortex of 2-weeks old albino rat offspring of bisphenol A (B2) treated mothers group shows a part of Purkinje cell (PC) that has ill-defined nucleus, swollen mitochondria with destructed cristae (Mi) and rough endoplasmic reticulum with normal appearance (RER). It also shows a basket cell (BC) that has shrunken nucleus with condensed clumps of heterochromatin $(\rightarrow)$ and cytoplasmic vacuoles (V). Notice the presence of a dendrite (D) contains numerous dilated rough endoplasmic reticulum (RER). (TEM X15000).

Fig. (2F): Electron micrographs of the internal granular cells of 2-weeks old albino rat offspring of bisphenol A (B2) treated mothers group show that an internal granular cell (IGC) has ill-defined outlines and shrunken nuclei with condensed clumps of heterochromatin $(\rightarrow)$. Other cells have heterochromatic nuclei $(\mathrm{N})$ with prominent nucleoli $(\mathrm{Nu})$, swollen mitochondria with destructed cristae (Mi) and rough endoplasmic reticulum with normal appearance (RER). (TEM X15000). 


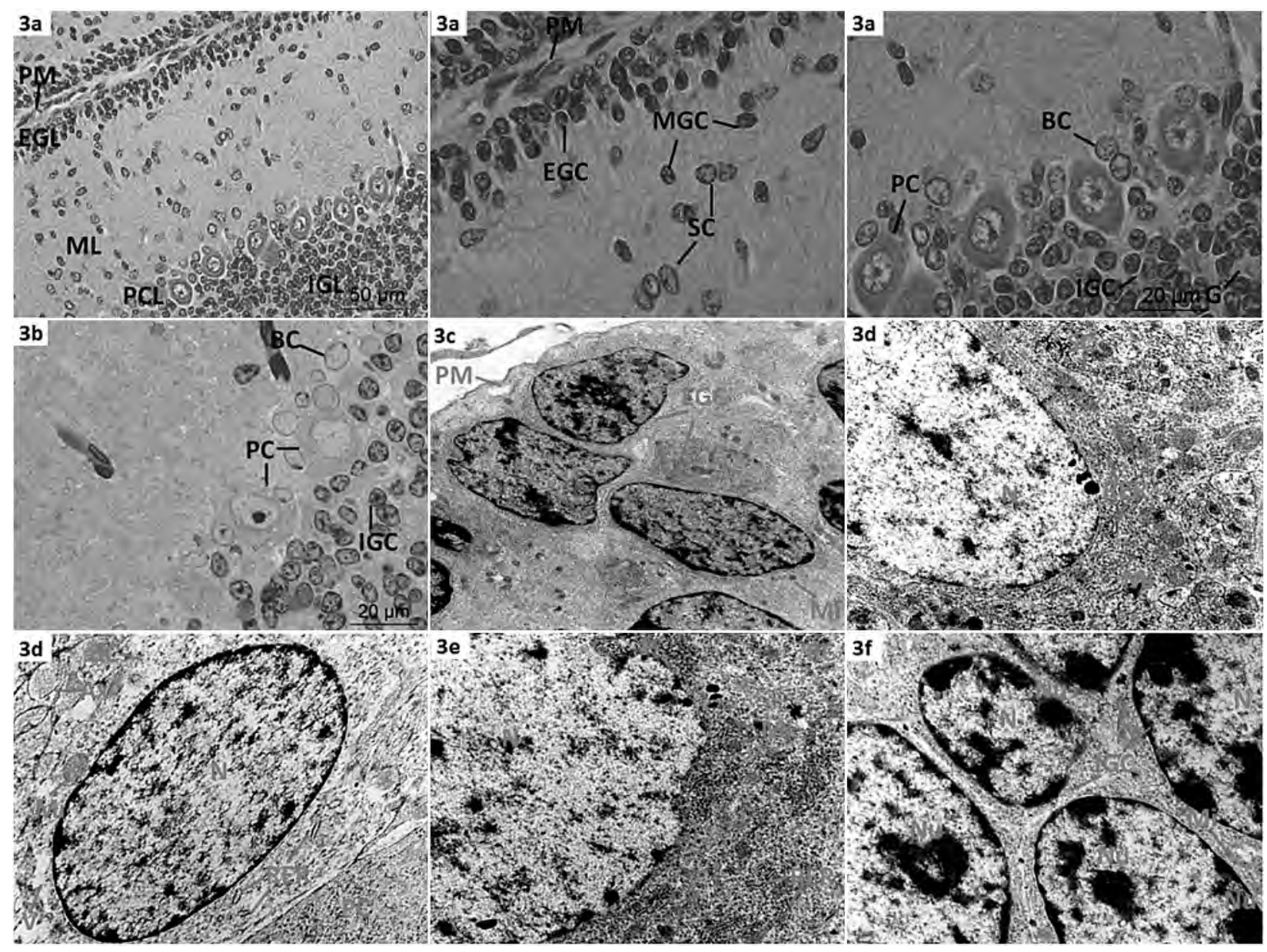

Fig. (3A): Photomicrographs of a median sagittal section of the cerebellar cortex of 2-weeks old albino rat offspring of combined bisphenol A and omega 3 (BO2) treated mothers group show that the cerebellar cortex consists of external granular layer (EGL) lies beneath the pia mater (PM), molecular layer (ML), Purkinje cell layer (PCL) and internal granular layer (IGL). The external granular cells (EGC) arrange in 2-5 rows. The stellate (SC), the basket (BC) and the Purkinje (PC) cells have normal appearance. Notice the presence of migrating granular cells (MGC). The internal granular cells (IGC) aggregate in clusters that are separated by the cerebellar glomeruli (G). (H. \& E. X400 \& X1000).

Fig. (3B): A photomicrograph of a median sagittal section of the lower part of the cerebellar cortex of 2-weeks old albino rat offspring of combined bisphenol A and omega 3 (BO2) treated mothers group shows that the basket (BC), the Purkinje (PC) and the internal granular (IGC) cells have nearly normal appearance. (Toluidine blue X1000).

Fig. (3C): Electron micrograph of the external granular cells of 2-weeks old albino rat offspring of combined bisphenol A and omega 3 (BO2) treated mothers group shows that the external granular cells (EGC) lie beneath the pia mater (PM). They have heterochromatic nuclei $(\mathrm{N})$ and mitochondria (Mi) with normal appearance. (TEM X15000).

Fig. (3D): Electron micrograph of the molecular layer of 2-weeks old albino rat offspring of combined bisphenol A and omega 3 (BO2) treated mothers group shows that the stellate (SC) and basket (BC) cells have euchromatic nuclei with small clumps of heterochromatin $(\mathrm{N})$, mitochondria $(\mathrm{Mi})$ and many rough endoplasmic reticulum with normal appearance. Notice the presence of small cytoplasmic vacuoles $(\mathrm{V})$ and few dilated rough endoplasmic reticulum (RER) within the basket cell (BC). Notice also the presence of axons (Ax) and part of a Purkinje cell (PC). (TEM X15000).

Fig. (3E): Electron micrograph of a Purkinje cell of 2-weeks old albino rat offspring of combined bisphenol A and omega 3 (BO2) treated mothers group shows that the Purkinje cell (PC) has euchromatic nucleus $(\mathrm{N})$ with deep invagination $(2$ arrows), mitochondria (Mi) and rough endoplasmic reticulum (RER) with normal appearance. (TEM X15000).

Fig. (3F): Electron micrograph of the internal granular cells of 2-weeks old albino rat offspring of combined bisphenol A and omega 3 (BO2) treated mothers group shows that the internal granular cells (IGC) have heterochromatic nuclei (N) with eccentric nucleoli $(\mathrm{Nu})$ and few mitochondria with destructed cristae (Mi). (TEM X15000). 

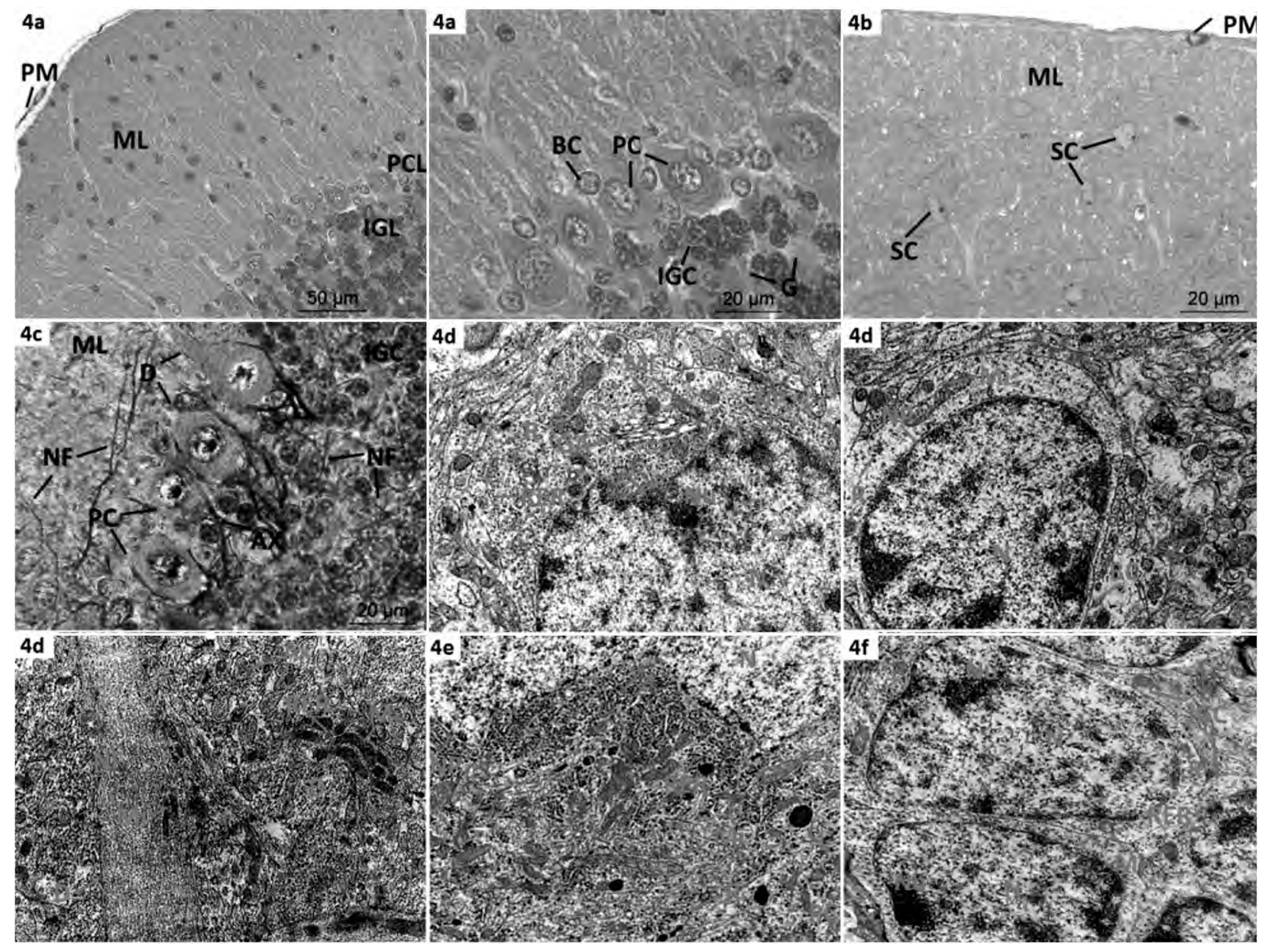

Fig. (4A): Photomicrographs of a median sagittal section of the cerebellar cortex of 8-weeks old offspring of the control (CN8 \& CR8) and omega 3 (O8) treated mothers groups show that the cerebellar cortex consists of molecular layer (ML) lies beneath the pia mater (PM), Purkinje cell layer (PCL) and internal granular layer (IGL). The basket cells (BC) have lightly stained nuclei with prominent nucleoli. The Purkinje cells (PC) have large central vesicular nuclei with prominent nucleoli. The internal granular cells (IGC) arrange in clusters that are separated by the cerebellar glomeruli (G). They have deeply stained nuclei with prominent nucleoli. (H. \& E. X400 \& X1000).

Fig. (4B): A photomicrograph of a median sagittal section of the upper part of the cerebellar cortex of 8-weeks old offspring of the control (CN8 \& CR8) and omega 3 (O8) treated mothers groups shows that the molecular layer (ML) lies beneath the pia mater (PM). The stellate cells (SC) have lightly stained nuclei with prominent nucleoli. (Toluidine blue X1000).

Fig. (4C): A photomicrograph of a median sagittal section of the lower part of the cerebellar cortex of 8-weeks old offspring of the control (CN8 \& CR8) and omega 3 (O8) treated mothers groups shows that the nerve fibers (NF) of the molecular layer (ML) appear as elongated brown filaments. The dendrites (D) of Purkinje cells are directed towards the molecular layer. The axons $(\mathrm{Ax})$ are directed towards the internal granular layer. The nerve fibers (NF) of the internal granular layer (IGL) appear long and extend in different directions. (Holmes' method silver staining X1000).

Fig. (4D): Electron micrographs of the molecular layer of 8-weeks old offspring of the control (CN8 \& CR8) and omega 3 (O8) treated mothers groups show that the stellate (SC) and basket (BC) cells have indented euchromatic nuclei with small clumps of heterochromatin $(\mathrm{N})$ and apparent nuclear pores (NP). In addition the stellate cell nucleus has deep invagination (2 arrows). Their cytoplasm contains free and clusters of ribosomes (R), rounded or elongated mitochondria (Mi), in addition the cytoplasm of the stellate cell contains rough endoplasmic reticulum (RER) and Golgi apparatus (GA). Notice the presence of axons (Ax) and dendrites (D) which contain mitochondria (Mi), rough endoplasmic reticulum (RER) and microtubules and neurofilaments (NF). (TEM X15000).

Fig. (4E): Electron micrograph of a Purkinje cell of 8-weeks old offspring of the control (CN8 \& CR8) and omega 3 (O3) treated mothers groups show that the Purkinje cell (PC) has euchromatic nucleus $(\mathrm{N})$ with deep invagination $(2$ arrows $)$ and apparent nuclear pores (NP), free and clusters of ribosomes (R), rough endoplasmic reticulum (RER), rounded and elongated mitochondria (Mi) and lysosomes (L). (TEM X15000).

Fig. (4F): Electron micrograph of the internal granular cells of 8-weeks old offspring of the control (CN8 \& CR8) and omega 3 (O3) treated mothers groups shows that the internal granular cells are closed with each other (IGC). They have heterochromatic nuclei $(\mathrm{N})$ with eccentric nucleoli $(\mathrm{Nu})$, free ribosomes $(\mathrm{R})$, few rough endoplasmic reticulum (RER) and small, rounded or elongated mitochondria (Mi). (TEM X15000). 

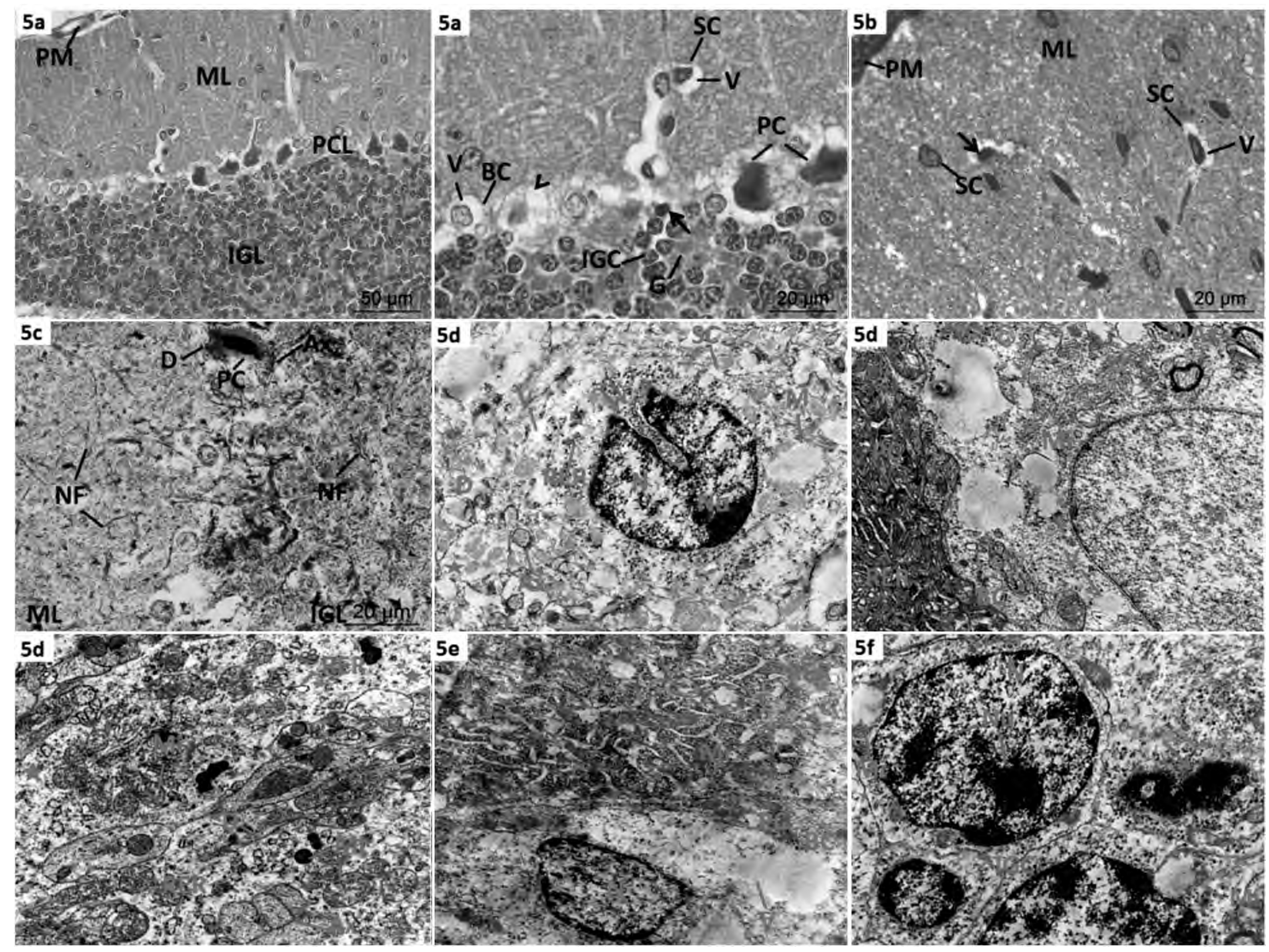

Fig. (5A): Photomicrographs of a median sagittal section of the cerebellar cortex of 8-weeks old albino rat offspring of bisphenol A (B8) treated mothers group show that the cerebellar cortex consists of molecular layer (ML) lies beneath the pia mater (PM), Purkinje cell layer (PCL) and internal granular layer (IGL). The stellate (SC) and basket cells (BC) have vacuolated cytoplasm (V). The Purkinje cells (PC) appear irregular in shape and have ill-defined nuclei and are surrounded by areas of vacuolations. Notice the presence of a Purkinje cell with nuclear disappearance leaving cellular debris (head arrow). The internal granular cells (IGC) aggregate in clusters that are separated by the cerebellar glomeruli (G). Notice the presence of cells with shrunken deeply stained nuclei $(\rightarrow)$. (H. \& E. X400 \& X1000).

Fig. (5B): A photomicrograph of a median sagittal section of the upper part of the cerebellar cortex of 8-weeks old albino rat offspring of bisphenol A (B8) treated mothers group shows that the molecular layer (ML) lies beneath the pia mater (PM). Few stellate cells (SC) appear irregular in shape, others have vacuolated cytoplasm (V) and shrunken deeply stained nuclei $(\rightarrow)$ (Toluidine blue X1000).

Fig. (5C): A photomicrograph of a median sagittal section of the lower part of the cerebellar cortex of 8-weeks old albino rat offspring of bisphenol A (B8) treated mothers group shows that the nerve fibers (NF) of the molecular layer (ML) are few, short and fragmented. The dendrites (D) and axons (Ax) of the Purkinje cells (PC) appear thin and short. The nerve fibers (NF) of the internal granular layer (IGL) are few and fragmented. (Holmes' method silver staining X1000).

Fig. (5D): Electron micrographs of the molecular layer of 8-weeks old albino rat offspring of bisphenol A (B8) treated mothers group show that a stellate cell appear with ill-defined outlines (SC) and has heterochromatic nucleus (N) with eccentric nucleolus $(\mathrm{Nu})$ and deep invagination (2 arrows), swollen mitochondria with destructed cristae (Mi) and numerous cytoplasmic vacuoles $(\mathrm{V})$. The basket cell $(\mathrm{BC})$ has euchromatic nucleus $(\mathrm{N})$, mitochondria with destructed cristae (Mi) and numerous cytoplasmic vacuoles (V). Notice the presence of part of a Purkinje cell (PC) with dilated rough endoplasmic reticulum (RER). Notice also the presence of axons (Ax), myelinated axons (MAx) and swollen dendrites (D) that contain dilated rough endoplasmic reticulum (RER), swollen and degenerated mitochondria (Mi) and areas of ill-defined structures (star). (TEM X15000).

Fig. (5E): Electron micrograph of a Purkinje cell of 8-weeks old albino rat offspring of bisphenol A (B8) treated mothers group show that the Purkinje cell (PC) has ill-defined nucleus, swollen mitochondria with destructed cristae (Mi) and dilated rough endoplasmic reticulum (RER). Notice the presence of a basket cell (BC) that has euchromatic nucleus with small clumps of heterochromatin $(\mathrm{N})$ and vacuolated cytoplasm (V). (TEM X15000).

Fig. (5F): Electron micrograph of internal granular cells of 8-weeks old albino rat offspring of bisphenol A (B8) treated mothers group shows that some internal granular cells (IGC) have heterochromatic nuclei $(\mathrm{N})$ with eccentric nucleoli $(\mathrm{Nu})$ and swollen mitochondria with destructed cristae (Mi). Notice the presence of an internal granular cell with ill-defined outlines and a shrunken and irregular nucleus with condensed clumps of heterochromatin $(\rightarrow)$. (TEM X15000). 

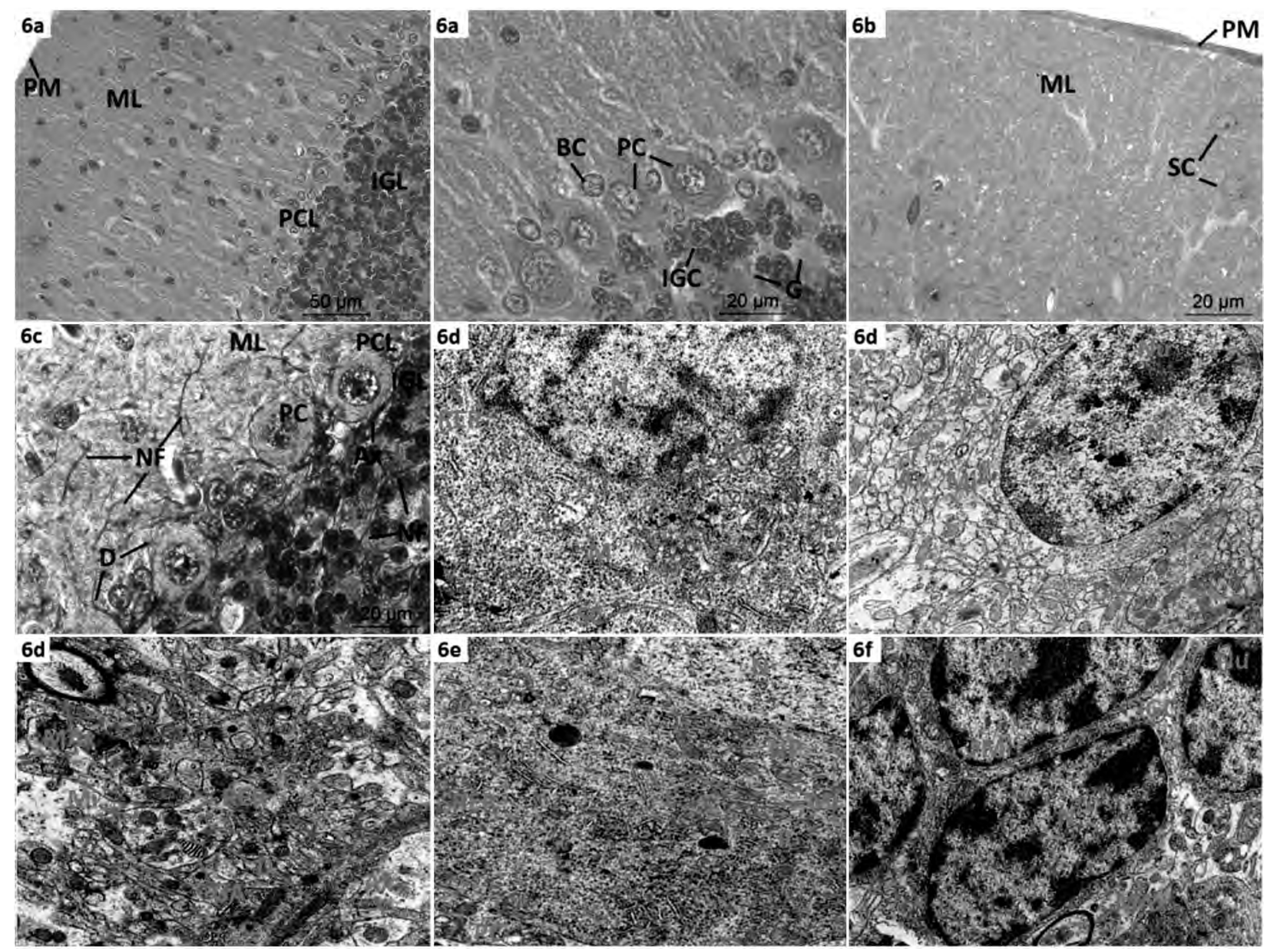

Fig. (6A): Photomicrographs of a median sagittal section of the cerebellar cortex of 8-weeks old albino rat offspring of combined bisphenol A and omega 3 (BO8) treated mothers group show that the cerebellar cortex consists of molecular layer (ML) lies beneath the pia mater (PM), Purkinje cell layer (PCL) and internal granular layer (IGL). The basket (BC), the Purkinje (PC) and the internal granular (IGC) cells have normal appearance. Notice the presence of the cerebellar glomeruli (G). (H. \& E. X400 \& X1000).

Fig. (6B): A photomicrograph of a median sagittal section of the upper part of the cerebellar cortex of 8-weeks old albino rat offspring of combined bisphenol A and omega 3 (BO8) treated mothers group shows that the molecular layer (ML) lies beneath the pia mater (PM). The stellate cells (SC) have lightly stained nuclei with prominent nucleoli. (Toluidine blue X1000).

Fig. (6C): A photomicrograph of a median sagittal section of the lower part of the cerebellar cortex of 8-weeks old albino rat offspring of combined bisphenol A and omega 3 (BO8) treated mothers group shows that the nerve fibers (NF) of the molecular layer (ML) are elongated brown filaments which are distributed in different directions. The dendrites (D) of Purkinje cells (PC) are directed towards the molecular layer. The axons (Ax) are directed towards the internal granular layer. The nerve fibers (NF) of the internal granular layer (IGL) appear long and extend in different directions. (Holmes' method silver staining $\mathrm{X}$ 1000).

Fig. (6D): Electron micrographs of the molecular layer of 8-weeks old albino rat offspring of combined bisphenol A and omega 3 (BO8) treated mothers group show that the stellate cell (SC) has euchromatic nucleus with small clumps of heterochromatin (N) and few mitochondria with destructed cristae (Mi). The basket cell (BC) has euchromatic nucleus with small clumps of heterochromatin $(\mathrm{N})$ with eccentric nucleoli $(\mathrm{Nu})$, small intracytoplasmic vacuoles $(\mathrm{V})$ and mitochondria with destructed cristae (Mi). Notice the presence axons (Ax), myelinated axons (MAx) and dendrites which contain mitochondria (Mi), rough endoplasmic reticulum (RER) and Golgi apparatus (GA) with normal appearance. (TEM X15000).

Fig. (6E): Electron micrograph of a Purkinje cell of 8-weeks old albino rat offspring of combined bisphenol A and omega 3 (BO8) treated mothers group shows that the Purkinje cell (PC) have euchromatic nucleus (N) with apparent nuclear pores (NP). Its cytoplasm contains mitochondria $(\mathrm{Mi})$, free ribosome $(\mathrm{R})$ and lysosomes $(\mathrm{L})$ with normal appearance and few dilated rough endoplasmic reticulum (RER). (TEM X15000).

Fig. (6F): Electron micrograph of the internal granular layer of 8-weeks old albino rat offspring of combined bisphenol A and omega 3 (BO8) treated mothers group shows that the internal granular cells (IGC) have heterochromatic nuclei (N) with eccentric nucleoli $(\mathrm{Nu})$ and few mitochondria with destructed cristae (Mi). Notice the presence of a myelinated axon (MAx). (TEM X15.000). 
Table (1): Means and standard deviations of the number of the Purkinje cells and the thickness of the molecular layer of the cerebellar cortex of the 2-weeks old offspring. It also shows one way ANOVA statistical analysis between groups $\mathrm{CN}, \mathrm{CR}, \mathrm{O}, \mathrm{B}$ and BO. Post Hok analysis using LSD test was applied to investigate the significance between the individual groups.

\begin{tabular}{|c|c|c|c|c|c|c|c|c|}
\hline 2 weeks & $\begin{array}{l}\text { Purkinje cell } \\
\text { (PC) count }\end{array}$ & Range & $\mathrm{F}$ & $p$-value & $\begin{array}{l}\text { Molecular layer } \\
\text { (ML) thickness }\end{array}$ & Range & $\mathrm{F}$ & $p$-value \\
\hline $\mathrm{CN}:$ Mean $\pm \mathrm{SD}$ & $25.13 \pm 3.52$ & $21-30$ & & & $192.21 \pm 30.28$ & $137.1-219.4$ & & \\
\hline CR: Mean \pm SD & $26.13 \pm 3.56$ & $22-32$ & & & $182.81 \pm 29.83$ & $149.2-230.5$ & & \\
\hline O: Mean \pm SD & $27.25 \pm 3.11$ & $23-32$ & 24.998 & $<0.001$ & $176.88 \pm 13.23$ & $159.9-201.5$ & 16.774 & $<0.001$ \\
\hline B: Mean \pm SD & $12.75 \pm 3.85$ & $5-17$ & & & $93.52 \pm 38.75$ & $49.3-144.1$ & & \\
\hline BO: Mean \pm SD & $24.50 \pm 2.51$ & $21-27$ & & & $174.76 \pm 18.21$ & $149.2-208.7$ & & \\
\hline
\end{tabular}

Post Hoc analysis by LDS

\begin{tabular}{lcccccccccc}
\hline Variable & CN vs. & CN vs. & CN vs. & CN vs. & CR vs. & CR vs. & CR vs. & O vs. & O vs. & B vs. \\
& CR & $\mathrm{O}$ & $\mathrm{B}$ & $\mathrm{BO}$ & $\mathrm{O}$ & $\mathrm{B}$ & $\mathrm{BO}$ & $\mathrm{B}$ & $\mathrm{BO}$ & $\mathrm{BO}$ \\
\hline$p$-value of PC count & 0.553 & 0.212 & 0.000 & 0.711 & 0.505 & 0.000 & 0.337 & 0.000 & 0.109 & 0.000 \\
$p$-value of ML thickness & 0.501 & 0.274 & 0.000 & 0.215 & 0.670 & 0.000 & 0.564 & 0.000 & 0.879 & 0.000 \\
\hline
\end{tabular}

$p$-value $>0.05$ non significant.

$p$-value $<0.05$ significant.

$p$-value $<0.01$ highly significant.

Table (2): Means and standard deviations of the number of the Purkinje cells and the thickness of the molecular layer of the cerebellar cortex of the 8-weeks old offspring. It also shows one way ANOVA statistical analysis between groups CN, CR, O, B and BO. Post Hok analysis using LSD test was applied to investigate the significance between the studied groups.

\begin{tabular}{|c|c|c|c|c|c|c|c|c|}
\hline 8 weeks & $\begin{array}{l}\text { Purkinje cell } \\
\text { (PC) count }\end{array}$ & Range & F & $p$-value & $\begin{array}{l}\text { Molecular layer } \\
\text { (ML) thickness }\end{array}$ & Range & $\mathrm{F}$ & $p$-value \\
\hline CN: Mean \pm SD & $25.63 \pm 4.03$ & $20-32$ & & & $160.98 \pm 25.62$ & 131.8-209.9 & & \\
\hline CR: Mean \pm SD & $25.75 \pm 4.20$ & $19-32$ & & & $190.61 \pm 53.01$ & $134.8-274.1$ & & \\
\hline O: Mean \pm SD & $25.00 \pm 3.85$ & $21-32$ & 4.257 & $<0.007$ & $196.68 \pm 19.67$ & $170.9-226.6$ & 9.521 & $<0.001$ \\
\hline B: Mean \pm SD & $19.38 \pm 2.67$ & $16-23$ & & & $103.86 \pm 30.78$ & $66.30-167.20$ & & \\
\hline BO: Mean \pm SD & $25.63 \pm 3.93$ & $20-32$ & & & $185.63 \pm 36.02$ & $150.3-243.5$ & & \\
\hline
\end{tabular}

Post Hoc analysis by LDS

\begin{tabular}{lcccccccccc}
\hline Variable & CN vs. & CN vs. & CN vs. & CN vs. & CR vs. & CR vs. & CR vs. & O vs. & O vs. & B vs. \\
& CR & O & B & BO & O & B & BO & B & BO & BO \\
\hline$p$-value of PC count & 0.948 & 0.743 & 0.002 & 1.000 & 0.694 & 0.002 & 0.948 & 0.005 & 0.743 & 0.002 \\
$p$-value of ML thickness & 0.114 & 0.059 & 0.002 & 0.186 & 0.742 & 0.000 & 0.787 & 0.000 & 0.549 & 0.000 \\
\hline$p$-value $>0.05$ non significant. & \multicolumn{1}{c}{$p$-value $<0.05$ significant. } & \multicolumn{2}{c}{$p$-value $<0.01$ highly significant. } &
\end{tabular}

\section{Discussion}

In the present work, it was found that bisphenol A induced various signs of delayed development in the cerebellar cortex of 2 and 8 weeks old offspring of treated mothers. These signs were in the form of increase the rows of external granular cells, irregularity in the shape of cerebellar cells, highly significant decrease of the thickness of the molecular layers in addition to thinning and fragmentation of nerve fibers. This finding was in line with [22] who stated that bisphenol A interferes with differentiation of ectodermal tissues, including neural tissues, in cynomolgus Monkeys. Also, [23] reported that bisphenol A significantly inhibited the dendritic development of Purkinje cells. In addition, $[\mathbf{2 4 , 2 5 ]}$ reported that bisphenol A exposure during gestation could disrupt fetal brain development/function or neuronal differentiation. Also it could affect neurogenesis during gestation or in young adult mice. Moreover, [26] reported that bisphenol A induced an increase in the thickness of the external granular layer in 11 days old mice offspring. Also, [27] said that exposure of pregnant mice to bisphenol A at an oral dose of $0.010 \mathrm{mg} / \mathrm{kg}$ bw/day had been shown to alter urinary tract, prostate and mammary glands development in the offspring. Also, [28] reported that Bisphenol A induced a delay in male rat mammary gland development, evidenced by reduced ductal growth, decreased number of terminal structures and lower expression of androgen receptor. In addition, [29] reported that bisphenol A severely retards fetal lung maturation in mouse. Moreover, [30] reported that bisphenol A prenatally exposed fetal mouse delayed pancreatic development.

The possible causes of delayed development of the offspring cerebrallar cortex could be due to passage of bisphenol A through the placenta or 
milk during lactation. The bisphenol A might pass through the blood brain barrier and after that affected several gens important for normal development. This suggestion coincided with $[31,32]$ who reported that 5 or $10 \mathrm{~g} / \mathrm{m}$ - bisphenol $A$ in the drinking water of a pregnant mouse resulted in 109 to $10-7 \mathrm{M}$ concentrations in the neonatal tissues. Also, [33] reported that Bisphenol A could be detected in the blood of pregnant women, amniotic fluid, placental tissue, umbilical cord blood and foetal serum indicating some degree of fetal exposure. Also, [34,35] said that bisphenol A was a lipophilic compound. Hence, it was proved that bisphenol A was capable of penetrating the bloodbrain barrier. In addition, [36-38] stated that Bisphenol A had been reported to affect the central nervous system during the embryonic development by suppression of Pax6 which had been shown to be a key regulatory gene for the proper differentiation of the granule cells and is necessary for polarization and migration of the granule neurons from the external granular layer to the internal granular layer. Also, [39,40] reported that Bisphenol A exposure was associated with the change in the methylation degree of several genes, the methylation status of which is developmentally stage dependent. In addition, $[41,42]$ reported that modification of histone remodeling had been associated with neurodevelopment defects and it had been shown that bisphenol A modifies histon mark. Also, [43] reported that bisphenol A induced changes in both dendritic and synaptic development in foetal rat hypothalamic cells via alteration of microtubuleassociated protein 2 and synapsin I expression, which served as protein markers of neuronal growth and synaptogenesis, respectively. Also, [44] reported that disruption of neurogenesis and neuronal migration in some brain areas of embryo mouse after maternal exposure to bisphenol A were possibly due to the up regulation of several early genes involved in cell migration and differentiation. Furthermore, [45-47] stated that due to estrogenic and antiandrogenic activities of bisphenol $\mathrm{A}$, it could interfere with the dimorphic development of the neuronal networks controlling many endocrine systems and brain functions.

In the present work, it was found that combined administration of omega 3 with bisphenol A alleviated the signs of delayed development of the cerebellar cortex of the 2 and 8 weeks old offspring of bisphenol A treated mothers. This finding coincided with [11] who reported that the polyunsaturated fatty acids were required for normal growth and maturaion of many organs, most importantly the brain and eye. Also, [48-50] stated that the majority of data suggested that omega-3 fatty acid intake during pregnancy was important for fetal brain development and the child's subsequent neurodevelopment, and that omega-3 fatty acid deprivation during pregnancy was associated with impaired developmental and behavioral scores. Also, [51] said that the mothers who ate more than 340 $\mathrm{g}$ per week of seafood had children with no worse outcomes than children born to women who ate less than that amount of seafood. Children born to mothers who reported no seafood intake had the greatest risk of adverse outcomes.

The possible protective effect of omega 3 on delayed development effects of bisphenol A could be due to improving membrane fluidity and promoting nerve growth factors in the brain. This suggestion was supported by $[\mathbf{5 2 , 5 3 ]}$ who reported that docosahexaenoic acid promoted nerve growth factor expression in the brain and promoted neuronal differentiation and arborization. Moreover, it accumulated in the neuronal growth cones during gestation where it played an important role in growth cone membrane signaling dynamics and synaptogenesis. Also, [54] stated that the docosahexaenoic acid could act to improve membrane fluidity, enhance synaptic transmission and increase receptor trafficking. It could also activated energy generating metabolic pathways that increase levels of growth factors including brain-derived neurotrophic factor and insulin growth factor-1. These growth factors could activate signaling cascades and enhance synaptic plasticity and transcription of genes involved in neuronal growth and development.

In the present work, it was found that bisphenol A induced various sgins of degeneration and necrosis in the cells and nerve fibers of the crebellar cortex of 2 and 8 weeks old offspring of bisphenol A treated mothers. These signs were in the form of highly significant decrease in the numbers of Purkinje cells, cytoplasmic vacuoles, swollen mitochondria with destructed cristae, degenerated mitochondria, dilated rough endoplasmic reticulum and nuclear changes in the form of karyolysis, pyknosis, karyorhexis and nuclear disappearance. These findings were in agreement with [55] who stated that bisphenol A induced apoptosis in the central neurons of tadpoles. Also, [56] reported significantly decreased sperm motility and an increased percentage of abnormal sperm following subcutaneous injection of high dose of bisphenol $\mathrm{A}, \sim 25 \mathrm{mg} / \mathrm{kg}$ bw/day, to neonatal mice. Also, [57] stated that bisphenol A exposure caused testicular changes including loss of typical lobular structure, reduction of spermatogenic cells and lobule diameter. Also, [58] said that bisphenol A lead to apop- 
tosis of Leydig and germ cells and disruption of spermatogenesis in mice. Meanwhile, [59] reported that postnatal exposure of mouse to bisphenol A resulted in slowed meiotic progression of germ cells with decreased quality and quantity of spermatozoa. Also, [60] reported that bisphenol A exposure induced significant induction of apoptosis in the testicular tissue of mice. In addition, [61] reported that bisphenol A induced mitochondria mediated apoptosis in hepatic cells. Also, [62] reported that bisphenol A induced various signs of nuclear degenerative changes as karyorhexis and karyolysis in the liver, kidney and spleen of adult male albino rats. Also, [63] reported that Bisphenol A induced liver fibrosis, and apoptosis in male rat. Moreover, [64] reported that bisphenol A induced degenerative changes in the liver and ovary of female rat.

The possible cause of degenerative effect of bisphenol A might be due to increased oxidative stress with decreased antioxidant enzyme activities that induced nuclear DNA damage of cerebellar cells and nerve fibers. This suggestion was in agreement with [65] and Kabuto et al., [31] who suggested that bisphenol A induced tissue injury in the liver, kidney, brain, and other organs by the formation of reactive oxygen species, decreasing the activities of antioxidant enzymes and increasing lipid peroxidation, thereby causing oxidative stress. Also, [10] declared that bisphenol A generated significantly high concentrations of malondialdehyde in the brain and sperm of male rats by induction of oxidative damage in the brain and testes of rats. In addition, [66] reported that early life exposure to bisphenol A significantly increased oxidative stress, decreased antioxidant enzyme activites and induced DNA damage in the liver of the female rat offspring.

In the present work, it was found that combined administration of omega 3 with bisphenol A lead to marked improvement of signs of degeneration and necrosis of the cells and nerve fibers of cerebellar cortex induced by bisphenol A. This finding coincided with [67] who reported that maternal omega-3 supplementation in an experimental study was suggested to limit periventricular white matter damage caused by infections during pregnancy. Also, [68] stated that Omega-3 prevents myelin and nerve degeneration in rat fetuses in low-dose radiation exposure. Also, [69] reported that omega-3 supplemented aged mice reduced neurodegeneration, thus supporting a role of omega-3 supplementation in preventing cognitive decline during aging. In addition, [70] reported that melatonin and omega-
3 were determined to exhibit neuroprotective effects following electromagnetic fields exposure.

The anti-degenerative effect of the omega 3 could be due to its antioxidant effects. This suggestion was in line with [14] who reported that Omega-3 fatty acids were found in high concentrations in neuronal membranes and had antioxidant properties. Also, [71-73] reported that omega-3 had an anti-apoptotic effect on developing brain and were used in treatment of cancer and cardiovascular diseases. In addition, [74] stated that exposure of formaldehyde increased free radicals in cerebellum of rats and this increase was prevented by administration of omega-3 fatty acids. Moreover, [75] reported that postnatal omega-3 supplementation was able to increase glutathione levels and reduced lipid peroxidation in pre natal ethanol exposure animals.

In this work, it was found that on bisphenol A withdrawal, the deleterious effects on the cerebellar cortex were irreversible. This finding coincided with [76] who said that delayed onset of puberty had been reported in female offspring of rats orally treated with bisphenol A at $50 \mathrm{mg} / \mathrm{kg}$ bw/day during gestation. Also, [77,78] reported that prenatal bisphenol A exposure had been shown to cause persistent aberrations in learning, memory and spontaneous behavior in rodents. Also, [79,80] reported that the interference with the early phases of CNS embryonic/fetal/neonatal development made permanent changes that prime and altered brain physiology not only in the exposed animals, but even in their offspring. On the other hand this finding was contrary to $[\mathbf{8 1 , 8 2 ]}$ who reported that no effect on onset of puberty in female rats exposed during gestation and lactation at maternal bisphenol A oral doses ranging from 3.2 to $\sim 1000 \mathrm{mg} / \mathrm{kg}$ bw/day. One high dose study reported an accelerated onset of puberty in female rats following subcutaneous injection of bisphenol A during early postnatal life at 105 and $427 \mathrm{mg} / \mathrm{kg}$ bw/day.

\section{Conclusion and Recommendations:}

Bisphenol A induced various deleterious changes in the histological structure of the cerebellar cortex of albino rat's offspring of treated mothers throughout pregnancy and lactation. These changes were irreversible on withdrawal of bisphenol A. On the other hand combined administration of omega 3 with bisphenol A alleviated most of these changes. So the exposure to bisphenol A must be avoided as much as possible during pregnancy and lactation and we advise in these cases to receive omega 3 capsules as a protectant against the side effects of bisphenol A. 


\section{References}

1- SHELBY M.D.: NTP-CERHR monograph on the potential human reproductive and developmental effects of bisphenol A. NTP Cerhr. Mon., (22): 1-64, 2008.

2- VANDENBERG L.N., MAFFINI M.V. and SONNENSCHEIN C.: Bisphenol-A and the great divide: A review of controversies in the field of endocrine disruption. Endocr. Rev., 30: 75-95, 2009.

3- CALAFAT A.M., KUKLENYIK Z., REIDY J.A., CAUDILL S.P., EKONG J. and NEEDHAM L.L.: Urinary concentrations of bisphenol A and 4-nonylphenol in a human reference population. Environ. Health Perspect., 113: 391-5, 2005.

4- RUBIN B.S. and BISPHENOL A.: An endocrine disruptor with widespread exposure and multiple effects. J. Steroid Biochem. Mol. Biol., 127: 27-34, 2011.

5- LOPEZ-ESPINOSA M.J., GRANADA A. and ARAQUE P.: Oestrogenicity of paper and cardboard extracts used as food containers. Food Addit. Contam., 24: 95-102, 2007.

6- WILSON N.K., CHUANG J.C., MORGAN M.K., LORDO R.A. and SHELDON L.S.: An observational study of the potential exposures of preschool children to pentachlorophenol, bisphenol-A, and nonylphenol at home and daycare. Environ. Res., 103: 9-20, 2007.

7- VON GOETZ N., WORMUTH M. and SCHERINGER M.: Bisphenol A: How the most relevant exposure sources contribute to total consumer exposure. Risk Anal., 30: 473-87, 2010.

8- LE H., CARLSON E.M., CHUA J.P. and BELCHER S.M.: Bisphenol A is released from polycarbonate drinking bottles and mimics the neurotoxic actions of estrogen in developing cerebellar neurons. Toxicol., 176 (2): 149-56, 2008.

9- ASIMAKOPOULOS A.G., THOMAIDIS N.S. and KOUPPARIS M.A.: Recent trends in biomonitoring of bisphenol A, 4-t-octylphenol, and 4-nonylphenol. Toxicol Lett., 210: 141-54, 2012.

10- AYDOGAN M., KORKMAZ A., BARLAS N. and KOLANKAYA D.: Pro-oxidant effect of vitamin C coadministration with bisphenol A, nonylphenol, and octylphenol on the reproductive tract of male rats. Drug Chem. Toxicol., 33: 193-203, 2010.

11- INNIS S.M. and FRIESEN R.W.: Essential n-3 fatty acids in pregnant women and early visual acuity maturation in term infants. Am. J. Clin. Nutr., 87: 548-57, 2008.

12- KRIS-ETHERTON P.M., HARRIS W.S. and APPEL L.J.: American heart association. Nutrition committee. Fish consumption, fish oil, omega- 3 fatty acids, and cardiovascular disease, 107: 512-3, 2003.

13- KRIS-ETHERTON P.M., TAYLOR D.S., YU-POTH S., HUTH P., MORIARTY K. and FISHELL V.: Polyunsaturated fatty acids in the food chain in the United States. Am. J. Clin. Nutr., 71: S179- S188, 2000.

14- SARSILMAZ M., SONGUR A., OZYURT H., KUŞ I. and OZEN O.: Potential role of dietary omega-3 essential fatty acids on some oxidant/antioxidant parameters in rats' corpus striatum. Prostaglandins Leukot. Essent. Fatty Acids., 69 (4): 253-9, 2003.
15- WHO: Bisphenol A (BPA)-current state of knowledge and future actions by $\mathrm{WHO}$ and $\mathrm{FAO}$; INFOSAN Information Note No. 5/2009-Bisphenol A, 2009B.

16- PAGET G.E. and BARNES J.M.: "Evaluation of drug activities". Pharmacometrics: Vol. 1. New York Academic Press, pp. 161-2, 1964.

17- COVINGTON M.B.: Omega-3 fatty acids. Am. Fam. Physician., 1, 70 (1): 133-40, 2004.

18- BARCELLONA P.S., FANELLI O. and CAMPANA A.: Teratological study of etoperiodine in the rat and rabbit. Toxicology, 8 (1): 87-94, 1977.

19- BANCROFT J.D. and GAMBLE M.: Theory and practice of Histological Techniques. The 7 th ed. Philadelphia: Churchill Livingstone of Elsevier. PP., 172-86, 2013.

20- DRURY R.A.B. and WALLINGTON E.A.: "Carleton's histological technique" $5^{\text {th }}$ ed. Oxford, New York, Toronto, pp. 357-70, 1980.

21- MOULD R.F.: "Introductory medical statistics". 2 nded. Adam Hilger, Bristol and Philadelphia, pp. 17-26, 1989.

22- YAMAMOTO M., TASE N., OKUNO T., KONDO Y., AKIBA S., SHIMOZAWA N. and TERAO K.: Monitoring of gene expression in differentiation of embryoid bodies fromcynomolgus monkey embryonic stem cells in the presence of bisphenol A. J. Toxicol. Sci., 32: 301-10, 2007.

23- KIMURA-KURODA J., NAGATA I. and KURODA Y.: Disrupting effects of hydroxy-polychlorinated biphenyl (PCB) congeners on neuronal development of cerebellar Purkinje cells: A possible causal factor for developmental brain disorders? Chemosphere, 67 (9): S412-S420, 2007.

24- KIM M.E., PARK H.R., GONG E.J., CHOI S.Y., KIM H.S. and LEE J.: Exposure to bisphenol A appears to impair hippocampal neurogenesis and spatial learning and memory. Food Chem. Toxicol., 49: 3383-9, 2011.

25- JANG Y.J., PARK H.R., KIM T.H., YANG W.J., LEE J.J., CHOI S.Y., OH S.B. and LEE E.: High dose bisphenol A impairs hippocampal neurogenesis in female mice across generations. Toxicology, 296: 73-82, 2012.

26- MATHISEN G.H., YAZDANI M., RAKKESTAD K.E., ADEN P.K. and BODIN J.: Prenatal exposure to bisphenol A interferes with the development of cerebellar granule neurons in mice and chicken. Int. J. Dev. Neurosci., 31 (8): 762-9, 2013.

27- TIMMS B.G., HOWDESHELL K.L., BARTON L., BRADLEY S., RICHTER C.A. and VOM SAAL F.S.: Estrogenic chemicals in plastic and oral contraceptives disrupt development of the fetal mouse prostate and urethra. Proc. Natl. Acad. Sci. U S A., 102: 7014-9, 2005.

28- KASS L., DURANDO M., ALTAMIRANO G.A., MANFRONI-GHIBAUDO G.E., LUQUE E.H. and MUÑOZDE-TORO M.: Prenatal bisphenol A exposure delays the development of the male rat mammary gland. Reprod. Toxicol., 54: 37-46, 2015.

29- HIJAZI A., GUAN H., CERNEA M. and YANG K. Prenatal exposure to bisphenol A disrupts mouse fetal lung development. FASEB J., 29 (12): 4968-77, 2015.

30- WHITEHEAD R., GUAN H., ARANY E., CERNEA M. and YANG K.: Prenatal exposure to bisphenol A alters 
mouse fetal pancreatic morphology and islet composition Horm. Mol. Biol. Clin. Investig., 25 (3): 171-9, 2016.

31- KABUTO H., AMAKAWA M. and SHISHIBORI T.: Exposure to bisphenol A during embryonic/fetal life and infancy increases oxidative injury and causes underdevelopment of the brain and testis in mice. Life Sci., 74: 2931-40, 2004.

32- MIDORO-HORIUTI T., TIWARI R., WATSON C. and GOLDBLUM R.: Maternal bisphenol A exposure promotes the development of experimental asthma in mousepups. Environ. Health Perspect., 118: 273-7, 2010.

33- ENGEL S., LEVY B., LIU Z., KAPLAN D. and WOLFF M.: Xenobiotic phenols in early pregnancy amniotic fluid. Reprod. Toxicol., 21: 110-2, 2006.

34- SUN Y., NAKASHIMA M.N., TAKAHASHI M., KURODA N. and NAKASHIMA K.: Determination of bisphenol $\mathrm{A}$ in rat brain by micro dialysis and column switching high-performance liquid chromatography with fluorescence detection. Biomed. Chromatogr., 16 (5): 319-26, 2002.

35- KIM C., SAPIENZA P.P., ROSS I.A., JOHNSON W., LUU H.M. and HUTTER J.C.: Distribution of bisphenol $\mathrm{A}$ in the neuroendocrine organs of female rats. Toxicol. Ind. Health, 20: 41-50, 2004.

36- YAMASAKI T., KAWAJI K., ONO K., BITO H., HIRANO T., OSUMI N. and KENGAKU M.: Pax6 regulates granule cell polarization during parallel fiber formation in the developing cerebellum. Development, 128: 3133-44, 2001.

37- SWANSON D.J., TONG Y. and GOLDOWITZ D.: Disruption of cerebellar granule cell development in the Pax6 mutant, Sey mouse. Brain Res. Dev. Brain Res., 160: 17693, 2005.

38- BABA K., OKADA K., KINOSHITA T. and IMAOKA S.: Bisphenol A disrupts Notch signaling by inhibiting gamma-secretase activity and causes eye dysplasia of Xenopus laevis. Toxicol. Sci., 108: 344-55, 2009.

39- DOLINOY D., HUANG D. and JIRTLE R.: Maternal nutrient supplementation counteracts bisphenol A-induced DNA hypomethylation in early development. Proc. Natl. Acad. Sci. USA, 104: 13056-61, 2007.

40- WARITA K., MITSUHASHI T., OHTA K. and SUZUKI S.: Gene expression of epigenetic regulatory factors related to primary silencing mechanism is less susceptible to lower doses of bisphenol A in embryonic hypothalamic cells. J. Toxicol. Sci., 38: 285-9, 2013.

41- SINGH S. and LI S.: Epigenetic effects of environmental chemicals bisphenol A and phthalates. Int. J. Mol. Sci., 13: 10143-53, 2012.

42- CONTESTABILE A. and SINTONI S.: Histone acetylation in neurodevelopment. Curr. Pharm. Des., 19: 5043-50, 2013.

43- MUNDY W.R., ROBINETTE B., RADIO N.M. and FREUDENRICH T.M.: Protein biomarkers associated with growth and synaptogenesis in a cell culture model of neuronal development. Toxicology, 249: 220-9, 2008.

44- ITOH K., YAOI T. and FUSHIKI S.: Bisphenol A, an endocrine disrupting chemical, and brain development. Neuropathology, 32: 447-7, 2012.
45- JAZIN E. and CAHILL L.: Sex differences in molecular neuroscience: From fruit flies to humans. Nat. Rev. Neurosci., 11: 9-17, 2010.

46- WOLSTENHOLME J.T., RISSMAN E.F. and CONNELLY J.J.: The role of bisphenol A in shaping the brain, epigenome and behavior. Horm. Behav., 59: 230-96, 2011.

47- DELFOSSE V., GRIMALDI M., Le MAIRE A., BOURGUET W. and BALAGUER P.: Nuclear receptor profiling of bisphenol-A and its halogenated analogues. Vitam. Horm., 94: 229-51, 2014.

48- GRAHAM E.M., RUIS K.A. and HARTMAN A.L.: A systematic review of the role of intrapartum hypoxiaischemia in the causation of neonatal encephalopathy. Am. J. Obstet. Gynecol., 199: 587-95, 2008.

49- ZHANG W., HU X. and YANG W.: Omega-3 polyunsaturated fatty acid supplementation confers long-term neuroprotection against neonatal hypoxic-ischemic brain injury through anti-inflammatory actions. Stroke, 41 : 2341-7, 2010

50- BERMAN D.R., LIU Y.Q., BARKS J. and MOZURKEWICH E.: Docosahexaenoic acid confers neuroprotection in a rat model of perinatal hypoxia-ischemia potentiated by Escherichia coli lipopolysaccharide-induced systemic inflammation. Am. J. B.M.C. Med., 3-11, 2010.

51- HIBBELN J.R., DAVIS J.M. and STEER C.: Maternal seafood consumption in pregnancy and neurodevelopmental outcomes in childhood (ALSPAC study): An observational cohort study. Lancet, 369: 578-85, 2007.

52- IKEMOTO A., NITTA A., FURUKAWA S., OHISHI M., NAKAMURA A., FUJII Y. and OKUYAMA H.: Dietary n-3 fatty acid deficiency decreases nerve growth factor content in rat hippocampus, Neurosci. Lett., 285: 99-102, 2000 .

53- AUESTAD N. and INNIS S.M.: Dietary n-3 fatty acid restriction during gestation in rats: Neuronal cell body and growth-cone fatty acids, Am. J. Clin. Nutr., 71: 312S314 S, 2000 .

54- GOMEZ-PINILLA F.: Brain foods: the effects of nutrients on brain function. Nat. Rev. Neurosci., 9: 568-78, 2008.

55- OKA T., ADATI N., SHINKAI T., SAKUMA K., NISHIMURA T. and KUROSE K.: Bisphenol A induces apoptosis in central neural cells during early development of Xenopus laevis. Biochem. Biophys. Res. Commun., 312 (4): 877-82, 2003.

56- AIKAWA H., KOYAMA S., MATSUDA M., NAKAHASHI K., AKAZOME Y. and MORI T.: Relief effect of vitamin $\mathrm{A}$ on the decreased motility of sperm and the increased incidence of malformed sperm in mice exposed neonatally to bisphenol A. Cell Tissue Res., 315: 119-24, 2004.

57- MANDICH A., BOTTERO S., BENFENATI E., CEVASCO A., ERRATICO C., MAGGIONI S., MASSARI A., PEDEMONTE F. and VIGANÒ L.: In vivo exposure of carp to graded concentrations of bisphenol A. Gen. Comp. Endocrinol., 153: 15-24, 2007.

58- LI Y., SONG T., CAI Y. and ZHOU J.: Bisphenol A exposure induces apoptosis and upregulation of Fas/FasL and caspase- 3 expression in the testes of mice. Toxicol. Sci., 108: 427-36, 2009. 
59- ZHANG G.L., ZHANG X.F., FENG Y.M., LI L., HUYNH E., SUN X.F., SUN. Z.Y. and SHEN W.: Exposure to bisphenol A results in a decline in mouse spermatogenesis. Reprod. Fertil. Dev., 25: 847-59, 2013.

60- TIAN J., DING Y., SHE R., MA L., DU F., XIA K. and CHEN L.: Histologic study of testis injury after bisphenol A exposure in mice. Toxicol. Ind. Health, 33 (1): 36-45, 2017.

61- XIA W., JIANG Y., LI Y., WAN Y. and LIU J.: Early-life exposure to bisphenol A induces liver injury in rats involvement of mitochondria-mediated apoptosis. PLoS ONE, 9 (2): e90443-e90444, 2014.

62- AHMED W.M., MOSELHY W.A. and NABIL T.M.: Bisphenol A toxicity in adult male rats: Hematological, biochemical and histopathological approach. Global Veterinaria, 14 (2): 228-38, 2015.

63- ELSWEFY S., ABDALLAH F., ATTEIA H., WAHBA A. and HASAN R.: Inflammation, oxidative stress and apoptosis cascade implications in bisphenol A-induced liver fibrosis in male rats. Int. J. Exp. Pathol., 97 (5): 369-79, 2016

64- MOUSTAFA G. and AHMED A.: Impact of prenatal and postnatal exposure to bisphenol $\mathrm{A}$ on female rats in a two generational study: Genotoxic and immunohistochemical implications. Toxicology Reports, 3: 685-95, 2016.

65- BINDHUMOL V., CHITRA K.C. and MATHUR P.P.: Bisphenol A induces reactive oxygen species generation in the liver of male rats. Toxicology, 188: 117-24, 2003.

66- EID J.I., EISSA A.M. and EL-GHOR A.: Bisphenol A induces oxidative stress and DNA damage in hepatic tissue of female rat offspring. The Journal of Basic \& Applied Zoology, 71: 10-9, 2015.

67- TUZUN F., KUMRAL A., DILEK M. and OZBAL S.: Maternal omega- 3 fatty acid supplementation protects against lipopolysaccharide-induced white matter injury in the neonatal rat brain. The Journal of Maternal-Fetal and Neonatal Medicine, 25: 845-9, 2012.

68- ERKAY1RAN U., IS1K H., SEVEN A., BAT1OGLU A.S., KAYAALP D., CAYDERE M. and ERGUN Y.: Omega3 prevents myelin degeneration in rat foetuses exposed to radiation. J. Obstet. Gynaecol., 36 (4): 444-9, 2016

69- DEBORA C., MARCO P., PAOLA C., ALBERTO G. and DANIELA L.: Effects of Omega-3 Fatty Acid Supplementation on Cognitive Functions and Neural Substrates: A Voxel-Based Morphometry Study in Aged Mice. Front Aging. Neurosci., 8: 38, 2016.

70- ERDEM KOÇ G., KAPLAN S., ALTUN G., GÜMÜ S H., GÜLSÜM DENIZ Ö., AYDIN I., EMIN ONGER M. and ALTUNKAYNAK Z.: Neuroprotective effects of melatonin and omega-3 on hippocampal cells prenatally exposed to $900 \mathrm{MHz}$ electromagnetic fields. Int. J. Radiat. Biol., 21: 1-6, 2016.
71- HARDMAN W.E.: (n-3) Fatty acids and cancer therapy Journal of Nutrition, 34: 3427-30, 2004

72- BRESLOW J.L.: N-3 fatty acids and cardiovascular disease. American Journal of Clinical Nutrition, 83: 1477 82, 2006.

73- SINHA R.A., KHARE P., RAI A., MAURYA S.K., PATHAK A. and MOHAN V.: Anti-apoptotic role of omega-3-fatty acids in developing brain: Perinatal hypothyroid rat cerebellum as apoptotic model. International Journal of Developmental Neuroscience, 27: 377-83, 2009.

74- ZARARSIZ I., MEYDAN S., SARSILMAZ M., SONGUR A., OZEN O.A. and SOGUT S.: Protective effects of omega-3 essential fatty acids against formaldehydeinduced cerebellar damage in rats. Toxicol. Ind. Health, 27 (6): 489-95, 2011

75- PATTEN A.R., BROCARDO P.S. and CHRISTIE B.R. Omega-3 supplementation can restore glutathione levels and prevent oxidative damage caused by prenatal ethanol exposure. J. Nutr. Biochem., 24 (5): 760-9, 2013.

76- TINWELL H., HASEMAN J., LEFEVRE P.A., WALLIS N. and ASHBY J.: Normal sexual development of two strains of rat exposed in utero to low doses of bisphenol A. Toxicol. Sci., 68: 339-48, 2002.

77- TIAN Y.H., BAEK J.H., LEE S.Y. and JANG C.G.: Prenatal and postnatal exposure to bisphenol $\mathrm{A}$ induces anxiolytic behaviors and cognitive deficits in mice. Synapse, 64: 432-9, 2010.

78- NAKAMURA K., ITOH K., DAI H., HAN L., WANG X., KATO S., SUGIMOTO T. and FUSHIKI S.: Prenatal and lactational exposure to low-doses of bisphenol A alters adultmice behavior. Brain Dev., 34: 57-63, 2012.

79- DOERGE D., VANLANDINGHAM M., TWADDLE N.C and DELCLOS K.B.: Lactational transfer of bisphenol A in Sprague-Dawley rats. Toxicol. Lett., 199: 372-6, 2010.

80- MANIKKAM M., TRACEY R., GUERRERO-BOSAGNA C. and SKINNER M.K.: Plastics derived endocrine disruptors (BPA, DEHP and DBP) induce epigenetic transgenerational inheritance of obesity, reproductive disease and sperm epimutations. PLoS One, 8: e55387-e55388, 2013.

81- KWON S., STEDMAN D.B., ELSWICK B.A., CATTLEY R.C. and WELSCH F.: Pubertal development and reproductive functions of Crl: CD BR Sprague-Dawley rats exposed to bisphenol A during prenatal and postnatal development. Toxicol Sci., 55: 399-406, 2000.

82- KATO H., OTA T., FURUHASHI T., OHTA Y. and IGUCHI T.: Changes in reproductive organs of female rats treated with bisphenol A during the neonatal period. Reprod. Toxicol., 17: 283-8, 2003. 


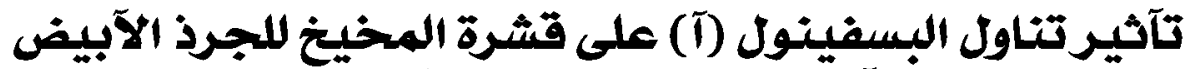

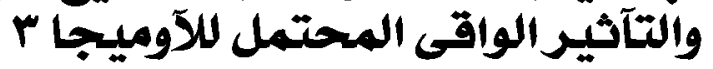

الخلفية: تعتبر مادة البسفينول آ الآكثر إستخداما تجاريا من مجموعات البيسفينول في صناعة البلاستيك. ووجد آن لها تآثير تأكسدى ضار في مخيخ الجرذان.

الهدف من العمل: إظهار التآثيرات الضارة لمادة البسفينهل آ (مهل/كجم/يوم) على قشرة مخيخ نسل الجرذان البيضاء للآمهات المعالجة

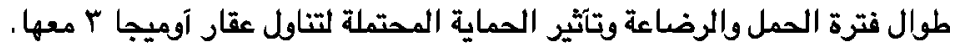
المواد والطرق: تم إستخدام خمسين من الجرذان البيضاء الصوامل وتم تقسيمهم إلى ع مجموعات:

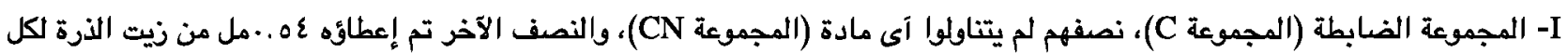
جرذ (المجموعة (CR).

II - المجموعة المعالجة بعقار الآوميجا ب (المجموعة O): تم إعطاء كل جرذ عه .. مل من زيت الذرة (يحتقى على ع مجم من عقار آوميجا ؟). III المجموعة المعالجة بمادة البسفينول آ (المجموعة B) تم إعطاء كل جرذ عه .. مل من زيت الذرة (يحتوى على ؟r.7مجم من مادة البسفينل

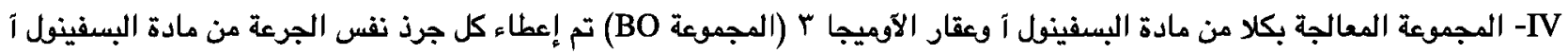

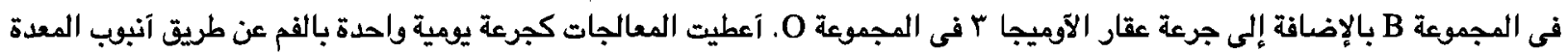
طوال فترة الممل ولمدة إسبوعين بعد الولادة. تم إستخلاص مخيخ الإهي نسل كل المجموعات في نهايات الإسابيع الثانية والثامنة وتم إعدادها

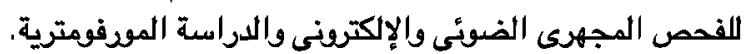

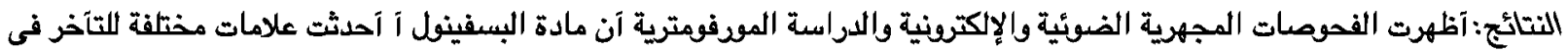
نمو قشرة المخيخ كما تسبيث فى إنحطاط ونخر الخلايا المخيخية والآلياف العصبية على شكل فجوات سيتوبلازمية، توبسع الشبكة الإندوبلازمية

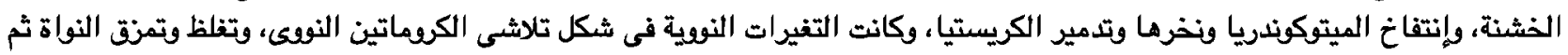

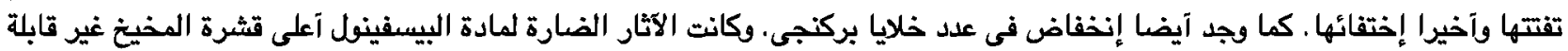

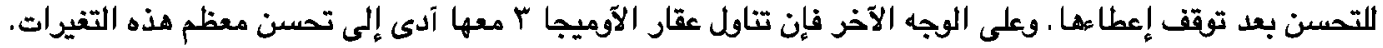

الإستتاج: آن تناول مادة البيسفينفل آ تسبيت في تغييرات ضارة مختفة في البنية النسيجية لقشرة المخيخ لنسل الجرذان البيضاء للآمهات الحوامل الاتى تم معالجتهن طوال فترة الحمل والرضاعة. وكانت هذه التغييرات غير قابلة للتحسن بعد توقف إعطاء مادة البسفينينول آ ومن ناحية آخرى حسن تناول عقار الآوميجا ب معها معظم هذه فرة التغييرات. 